\title{
Fleet-Car market PENetration simulator: “CPEN" USER'S GUIDE
}

\author{
RICHARD WEIL
}

\section{MASTER}

August 1980

\section{NATIONAL CENTER FOR ANALYSIS OF ENERGY SYSTEMS DEPARTMENT OF ENERGY AND ENVIRONMENT}

BROOKHAVEN NATIONAL LABORATORY UPTON, NEW YORK 11973

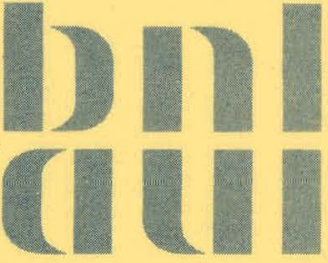




\section{DISCLAIMER}

This report was prepared as an account of work sponsored by an agency of the United States Government. Neither the United States Government nor any agency Thereof, nor any of their employees, makes any warranty, express or implied, or assumes any legal liability or responsibility for the accuracy, completeness, or usefulness of any information, apparatus, product, or process disclosed, or represents that its use would not infringe privately owned rights. Reference herein to any specific commercial product, process, or service by trade name, trademark, manufacturer, or otherwise does not necessarily constitute or imply its endorsement, recommendation, or favoring by the United States Government or any agency thereof. The views and opinions of authors expressed herein do not necessarily state or reflect those of the United States Government or any agency thereof. 


\section{DISCLAIMER}

Portions of this document may be illegible in electronic image products. Images are produced from the best available original document. 
(Energy Conservation--Trans-

portation - TIC-4500)

\title{
fleet-Car market PENetration SIMULATOR: "CPEN" \\ USER'S GUIDE
}

\author{
RICHARD WEIL
}

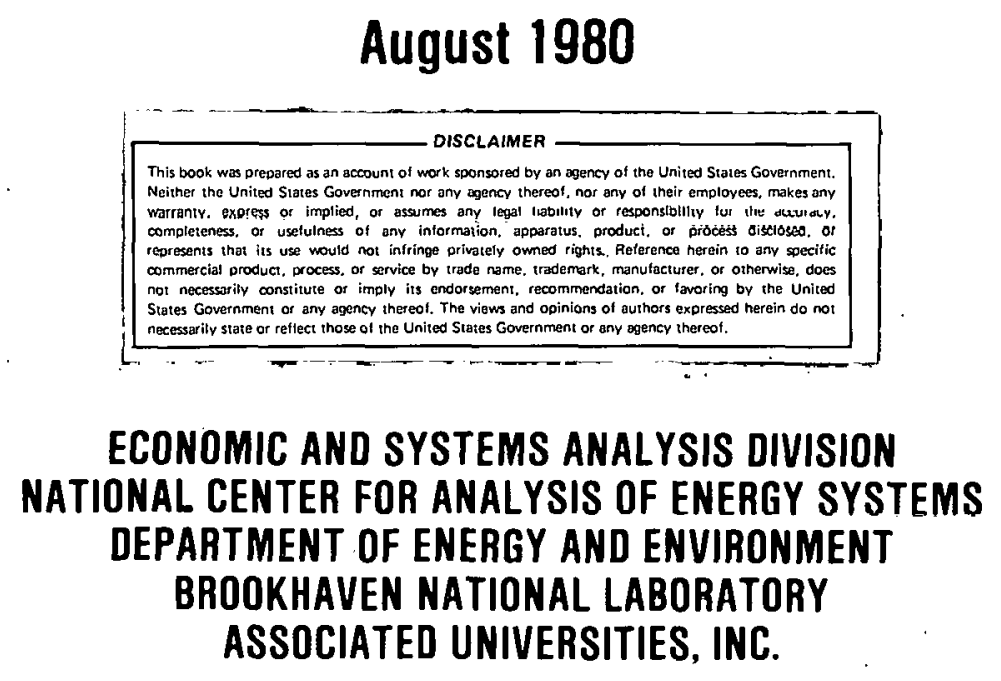

UNDER CONTRACT NO. DE-ACO2-76CH00016 WITH THE UNITED STATES DEPARTMENT OF ENERGY 
This report was prepared as an account of work sponsored by an agency of the United

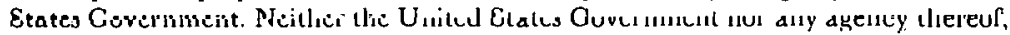
nor any of their employees, nor any of their contractors, subcontractors, or their employees, makes any warranty, express or implied, or assumes any legal liability or responsibility for the accuracy, completeness, or usefulness of any information, apparatus, profunct, or process disclosed, or represents that its use would not infringe privately owned rights. Reference herein to any specific commercial product, process, or service by trade name, trademark, manufacturer, or otherwise, does not necessarily constitute or imply its endorsement, recommendation, or favoring by the United States Government or any agency, contractor or subcontractor thereof. The views and opinions of authors expressed herein do not necessarily state or reflect those of the United States Government or any agency, contractor or subcontractor thereof.

Printed in the United States of America

Available from

National Technical Information Service

U.S. Department of Commerce

5285 Port Royal Road

Springfield, VA 22161

Price: Printed Copy $\$ 8.00$; Microfiche $\$ 3.50$ 
The purpose of this manual is to assist prospective users in the understanding and execution of Fleet-Car Market PENetration Simulator (CPEN). CPEN is an interactive FORTRAN program whose purpose is to produce estimates of fleet market penetration rates of alternative passenger cars that can be described in terms of specific physical and econonic attributes. The data were derived from questionnaries distributed to fleet operators affillated with National Association of Fleet Administrators (NAFA). Besides the NAFA data, CPEN uses 48 variables that are interactively inserted. Complete data input descriptions are included in the manual along with algorithm and application flowcharts. Examples of 'complete' successful simulator runs are included for alternative program paths. A listing of the computer program and a glossary for CPEN are included.

\section{ACKNOWLEDGMENTS}

The author would like to thank project manager Joseph $R$. Wagner for the understanding and support received while working under his supervision at BNI. Ronald Lattanz10, a graduate student from the state University of New. York at Stony Brook, was very helpful in assembling the data and the survey research. The author would like to thank Deborah Shonka for her consultation and support in the creation of the User's Guide. 


\section{THIS PAGE}

WAS INTENTIONALLY

LEFT BLANK 


\section{CONTENTS}

Abstract $\ldots \ldots \ldots \ldots \ldots \ldots \ldots \ldots \ldots \ldots \ldots \ldots \ldots \ldots \ldots \ldots \ldots \ldots \ldots \ldots \ldots \ldots \ldots \ldots \ldots \ldots \ldots$

Acknowledgments................................... iii

Tables........................................ vi

Figures......................................... vi

scope............................................. 1

NAFA Data........................................

Data File......................................... 3

Computer Program Abstract............................ 3

User Input Description................................ 5

Programming Information............................. 6

Application Information............................... 12

Problems and Diagnosis............................... 22

Bibliography....................................... 24

References....................................... 25

Appendix A: Sample Questionñaire........................ 27

B: User Input Sequence and Footnotes.............. 35

C: User Input. for Example........................ 39

U: Example kun $($ Short Parh) ................... 41.

E: Example Run (Long Path) ................... 45

F : output............................... 51

G: $\quad$ CPEN Glossary............................. 55

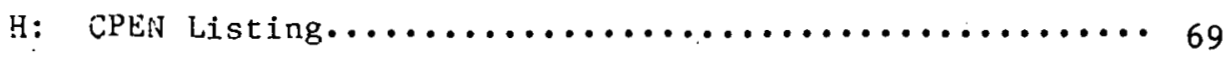




\section{TABLES}

1. NAFA Data....................................... 2

2. CAR Data Structure............................... 4

3. Sampling Rates and Sectoral Distribution of Cars............ 11

4. Physical Attributes.................................. 19

5. Economic Attributes................................... 19

\section{F IGURES}

1. CPEN Algorithm Flowchart.......................... 7

2. Illustration of. Applicability Overlap between EHV1 and EHV2.... 10

3. CPEN User Application Flowchart...................... 15 
$\underline{\text { SCOPE }}$

Eleet-Car Market PENetration Simulator (CPEN) is a FORTRAN program written for use on Brookhaven National Laboratory's CDC 6600 computer. It is an interactive program operable from remote (including non-BNL) terminals. The purpose of the program is to initially test the market applicability of two hypothetical electric or hybrid vehicles (EHV), termed EHV1 and EHV2, for the fleet industry. $F 1$ If an EHV has physical attributes that make it suitable for use in the market (i.e., if the EHV is applicable), then CPEN can be used to perform an economic comparison of the EHV and a comparable internal-combustion-engine (ICE) car, and determine which vehicle the respondent would purchase to minimize costs. Al1 CPEN dollar amounts are stated in March 1979 dollars. .

The program uses data Erom an "Electric Car Survey" comprised of information collected from 142 Fleet operators. The survey was designed under the guidance of Brookhaven National Laboratory (BNL) and was administered through the National Association of Fleet Administrators, Inc. (NAFA). Each fleet operator (respondent) was asked to indicate a preference for a base $\operatorname{car}^{\mathrm{F} 2}$ described in the questionnaire, or, alternatively, create up to three additional respondent-described "optional cars." He was then asked to indicate maximum prices he would be willing to pay for various physical attributes of the described cars and the percentage of his fleet that could function using each optional car (including the base car). These respondent-described cars, or optional cars, were then compared to hypothetical EHVs to determine applicability rates for the hypothetical EHVs.

\section{NAFA DATA}

The survey was administered to members of NAFA, who are located throughout the U. S. (see Appendix A for sample questionnaire). Each respondent is classified by. his main business activity or market sector. There are four market sectors. Of the 142 usable questionnaires that were returned, 111 were from respondents in the business sector, 7 were in utilities (e.g., gas and sanitary), 7 in police, and 17 in state and local government. The questionnaires sent to the business sector were divided into thirds, one third specifying base prices (Appendix A) of $\$ 2,000$, the second third specifying $\$ 4,000$, and the last third $\$ 6,000$. 
Table 1

NAFA Data

\begin{tabular}{lcccc}
\hline NAME & MIX \# & CASE NUMBERS & TOTAL CASES & BASE CASE \\
\hline Business & 1 & $1-30$ & 30 & $\$ 2,000$ \\
Business & 2 & $31-76$ & 46 & 4,000 \\
Business & 3 & $77-107$ & 31 & 6,000 \\
Communications & 4 & $108-111$ & 4 & 2,000 \\
Utilities & 5 & 112118 & 7 & 2,000 \\
Police & 6 & $119-125$ & 7 & 2,000 \\
State \& Local Gov't. & 7 & $126-142$ & 17 & 2,000 \\
\hline
\end{tabular}

* Mix 1 to 4 combined as Total Busincss with 111 cases in all.

Ail the other cases have a base price of $\$ 2,000$ (see Table 1 ).

The simulator was initiated by the design of an SPSS (Statistical Package for the Social Sciences) data file. From this file, frequency tables were executed for all variables testing the data for mistaken values. "The default value " -9 " was designated as the term for missing data. For example, many respondents did not request a third optional car, so the variables indicating the attributcs and maximum price valucs were read in as "-9". Although S̄PSS proved to be a good starting block, it lacked the sophistication necessary to build a complex simulator. Fortran Extended Version 4, with its interactive and formating capabilities, was found appropriate for the simulation. Since Fortran can be compiled (absolute binary form) and then executed on INTERCOM, F' 3 the actual time required to complete a run is substantially less than for other computer languages. 


\section{DATA FILE (MATRIX2)}

An SPSS program including the raw data was constructed from the questionnaire results. By deleting the SPSS control and language statements, only the raw data were left. A Fortran program was then created that extracted the necessary car data and cataloged (saved) it on a separate tape. Since the data are in the design of a matrix (array), the data tape was given the name 'MATRIX2'. For each of the 142 cases processed, there are 24 variables (see Table 2), for each of as many as four optional cars (counting the base car). The data matrix has dimensions 142 by 24 by 4 which correspond respectively to the case, variable, and optional car number, with the $4^{\text {th }}$ position representing the base car. For CPEN's internal usage, the data array is called CAR. CAR (I), where $I=1,2, \ldots, 24$, acts as a dummy $1 \times 24$ matrix that is overwritten each time a new respondent or new optional car is processed in the program. Table 2 lists the 24 variables in the exact order that they are stored in the CAR array.

\section{COMPUTER PROGRAM ABSTRACT}

As previously mentioned, CPEN is an interactive Fortran program used on Brookhaven National Laboratory's CDC 6600 computer. CPEN can also run on BNL's CDC 7600. Although the CDC 7600 does not possess the interactive capabilities of the $\mathrm{CDC} 6600$, the input data can be read in as a separate tape. This would defeat the purpose of an interactive program but it could be used to test programming logic. The CDC 7600 is also a convenient alternative if the CDC 6600 is inoperable.

The terminals typically used at BNL for CPEN executions are the DASI 360 and the DASI 735 (Data Access Systems Inc.). The DASI 360 has a carriage width of 136 characters and can properly print all CPEN output, whereas the DASI 735 carriage is not wide enough for Table B, and consequently the last column gets "wrapped-around" the front.

CPEN is cataloged at BNL by the name 'CPEN1' and is also stored in the compiled version 'CPENIABS'. The program can successfully run using either the compiled or the noncompiled version. The advantage of using the compiled version is that it is not necessary to compile the progran 


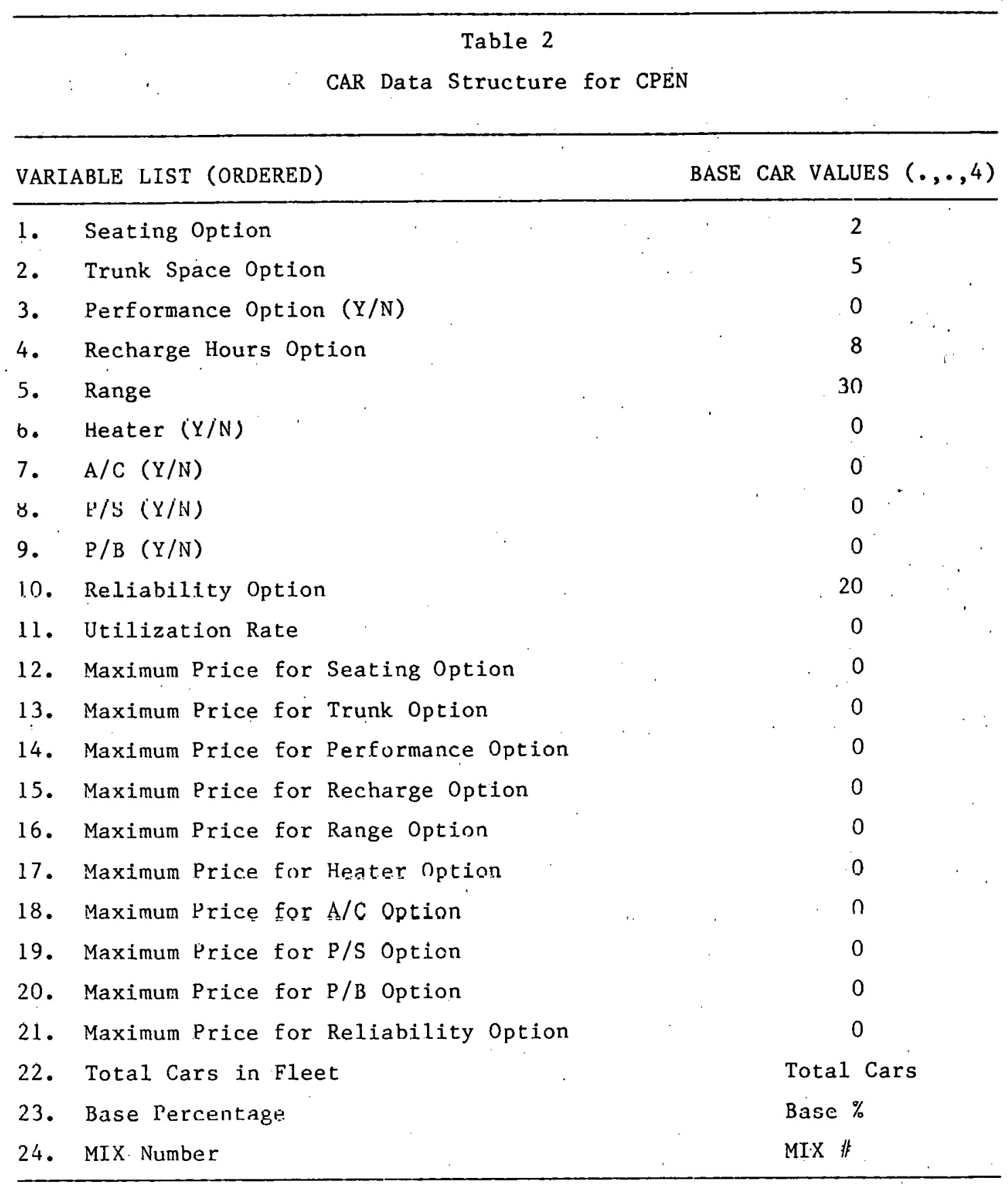


at every LOGIN, which saves money, time, and space on the computer. A common name for such a compiled version is the absolute binary of a program. Attaching the letters ABS at the end of a program's name indicates that the program is in the absolute binary. The following job was batched to store the compiled CPEN version of CPENIABS.

$$
\begin{aligned}
& 100=\text { WEIL, STMFA, T37,P2. } \\
& 110=\text { ACCOUNT (WEIL, 1074) } \\
& 120=\text { ROUTE (OUTPUT, TID=AI, DC-PR, DEF) } \\
& 130=\text { ATTACH (SR, CPENI, ID=WAGNER, MR=1) } \\
& 140=\text { FTN, I=SR, R=3. } \\
& 150=\text { REQUEST,ABS, *PF. } \\
& 160=\text { LOAD (LGO) } \\
& 170=\text { NOGO(ABS) } \\
& 180=\text { CATALOG, ABS, CPEN1ABS, ID=WAGNER, AC=1074, RP=999. } \\
& \ldots \text { S, Q, N } \\
& \ldots \text { BATCH, Q, INPUT }
\end{aligned}
$$

The CPEN model uses approximately $1.005 \mathrm{cp}$ seconds and $67500 \mathrm{~B} \mathrm{CM}$ storage units. The compilation time of CPEN1 is approximately $8.643 \mathrm{cp}$ seconds.

\section{USER INPUT DESCRIPTION}

In CPEN, there are 48 variables that are. input interactively by the user. The inputs consist of variables describing EHV1, EHV2, and three ICE cars (small, medium, and large). F4 Appendix $B$ indicates the actual input sequence of the variables.

The input variahles are divided into two sets. The first set contajins the physical attributes of EHV1 and EHV2. The variable names are self-explanatory, except for the reliability option which is the allowable annual number of unscheduled days the car has to spend in a repair shop. (Note that this value for the base car is 20 days.)

The second set describcs the economis attrihutes of EHVl, EHV2, and typical ICEs. Appendix B lists the actual variable input names to be 
used on the terminal. Refer to the Appendix. B footnotes for explanation of input names. The ICE variables contain the price of liquid fuel (\$/gal),.. price of electricity ( $\$ / \mathrm{kWh),} \mathrm{ICE} \mathrm{fuel} \mathrm{consumption} \mathrm{(mpg),} \mathrm{and}$ ICE prices (dollars). These values should all be converted into March 1979 dollars. F5

\section{PROGRAMMING INFORMATION}

\section{A. CPEN Background}

A companion BNL report describing the objectives and theory underlying CPEN will assist the user in the raaeoning and formulation of a test problem. A simplified flowchart of CPEN's algorithm is listed in Figure 1. F6

B. Output Information

The CPEN simulation simultaneously analyzes two types of electric and/or hybrid vehicles, identified as EHVL and EHV2. Four output tables are produced that indicate, the degree of success expected for the EHV1 and.:EHV2 in. the four fleet market sectors covered by the NAFA sample. No time dimension is associated with the estimates. That is, the estimates are not for any given year. Above all they are not a prediction of what will happen, but rather an indication of what would happen if:

1) The NAFA sample were representative or, stated differently, the ovcrall market seclues displayed the same preferences as the fleet operators in the NAFA sample.

2) Choice of vehicles were limited to EHVl, EHV2, and the ICEs described in the input' data.

3) Vehicle production capacity were capable of meeting demand.

4). The fleet market were operating under steady state conditions with. respect to preferences and total sales. 


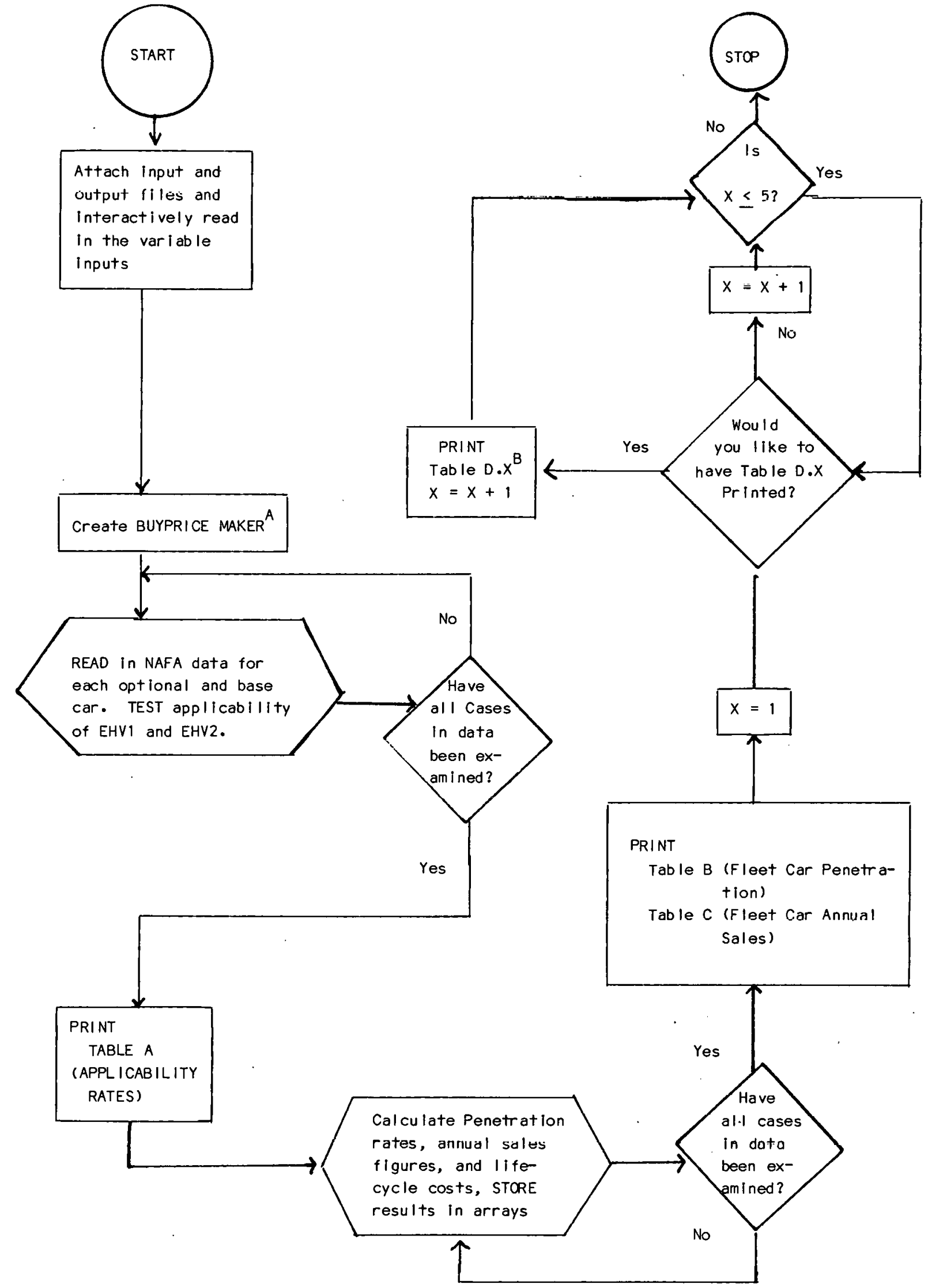

Figure 1. Simplified CPEN Flowchart for (Algorithm) 
A. The BUYPRICE MAKER takes the base price of each respondent's optional car and adds it to the sum of the maximum price values for all the attributes to give a final price of each optional car. Because of survey weaknesses, it was felt that some respondent's, price values were not credible. Final price values were raised if they were thought to be unrealistically low. For a small-sized car ( 4 or fewer seats) the price was raised to a minimum of $\$ 5,000$, $\$ 6.000$ for a medium-sized rar ( 5 sagts), and $\$ 6,900$ for a largcsized car ( 6 or more seats).

B. $\mathrm{X}-1, \ldots, j$ and eàch value represents:

1 - BUSINESS SECTOR

2 - UTILITIES SECTOR

3 - POLICE SECTOR

4 - GOV'T SECTOR

5 - ALL SECTORS

The first output table shows EHV applicability rates generated by comparing the physical attributes of EHVl and EHV2 to the required physical capabilities specified for cars operated by individual NAFA respondents. Note specifically that price is not a factor in applicability.

The generulized format of this table is presenced in Table A. The particular values in Table A indicate that EHVI is physically capable of substituting for 19 percent of the cars in the business sector, whereas EHV 2 could substitute for 13 percent in the same sector. If a given car could be replaced by either EHVl or EHV2, the amount will show up in the column called OVERLAP. Figure 2 is a Venn diagram of Table A. In order to determine the combined applicability for both EHVl and EHV2, add the first and second columne and then subtract the overlap. The bulluin row of Table A shows the weighted average applicability rates for all sectors. The weighting is based on the stock of cars in each sector (see Table 3). 


\begin{tabular}{lcccc}
\hline \multicolumn{5}{c}{ Table A } \\
Applicab1lity Rates (Percent) \\
SECTOR & EHV1 & EHV2 & OVERLAP & TOTAL \\
\hline BUS
\end{tabular}

Table B

Fleet Car Penetration Rates (Percent)

\begin{tabular}{|c|c|c|c|c|c|c|c|}
\hline \multirow[b]{3}{*}{ SECTOR } & \multirow{2}{*}{\multicolumn{3}{|c|}{ 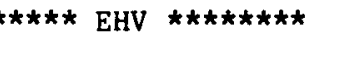 }} & \multicolumn{4}{|c|}{ 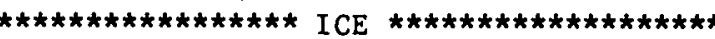 } \\
\hline & & & & & $\mathrm{Ni}-$ & & GRAND \\
\hline & EHV1 & EHV2 & TOTAL & APPLICABLE & APPLICABLE & TOTAL & TOTAL \\
\hline BUSINESS & .0 & 6.1 & 6.2 & 3.7 & 90.1 & 93.8 & 100.0 \\
\hline UTILITIES & 0.0 & 31.4 & 31.4 & 0.0 & 68.6 & 68.6 & 100.0 \\
\hline PÖLICE & 0.0 & .3 & .3 & .3 & 99.5 & 99.7 & $: 100.0$ \\
\hline GOV'T & 0.0 & 28.5 & 28.5 & 8.6 & 63.0 & 71.5 & $1,00.0$ \\
\hline TOTAL & .0 & 11.7 & 11.8 & 3.8 & 84.5 & 88.2 & 100.0 \\
\hline
\end{tabular}

\begin{tabular}{|c|c|c|c|c|c|c|c|}
\hline \multirow[b]{3}{*}{ SECTOR } & \multirow{3}{*}{$\begin{array}{l}\star \star \star \star \star \star \star \\
\text { EHVI }\end{array}$} & \multicolumn{6}{|c|}{$\begin{array}{c}\text { Table C } \\
\text { Fleet Car Annual Sales (Thousands) }\end{array}$} \\
\hline & & \multicolumn{2}{|c|}{ 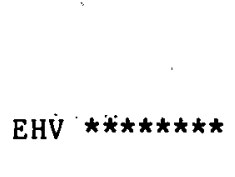 } & \multirow[b]{2}{*}{ ICE } & \multirow[b]{2}{*}{ TOTAL } & \multicolumn{2}{|c|}{ 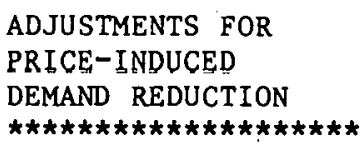 } \\
\hline & & EHV2 & TOTAL & & & $\begin{array}{l}\text { DEMAND } \\
\text { REDUCTION }\end{array}$ & $\begin{array}{l}\text { ORIGINAL } \\
\text { DEMAND }\end{array}$ \\
\hline BUS INESS & 0. & 24. & 24. & 360. & 384. & 511. & 895. \\
\hline UTILITIES & 0. & 3. & 3. & 7. & 10. & 46. & 56. \\
\hline POLICE & 0. & 0. & 0. & 66. & 66. & 21 & 87. \\
\hline GOV'T & 0. & 6. & 6. & 14. & 20. & 79. & 99. \\
\hline TOTAL & 0. & 33. & 33. & 448. & 480. & 657. & 1137. \\
\hline
\end{tabular}


TOTAL FLEET MARKET

MARKET SHARE FOR

WHICH EHV2 IS

MARKET SHARE FOR

WHICH EHV 1

IS APPLICABLE

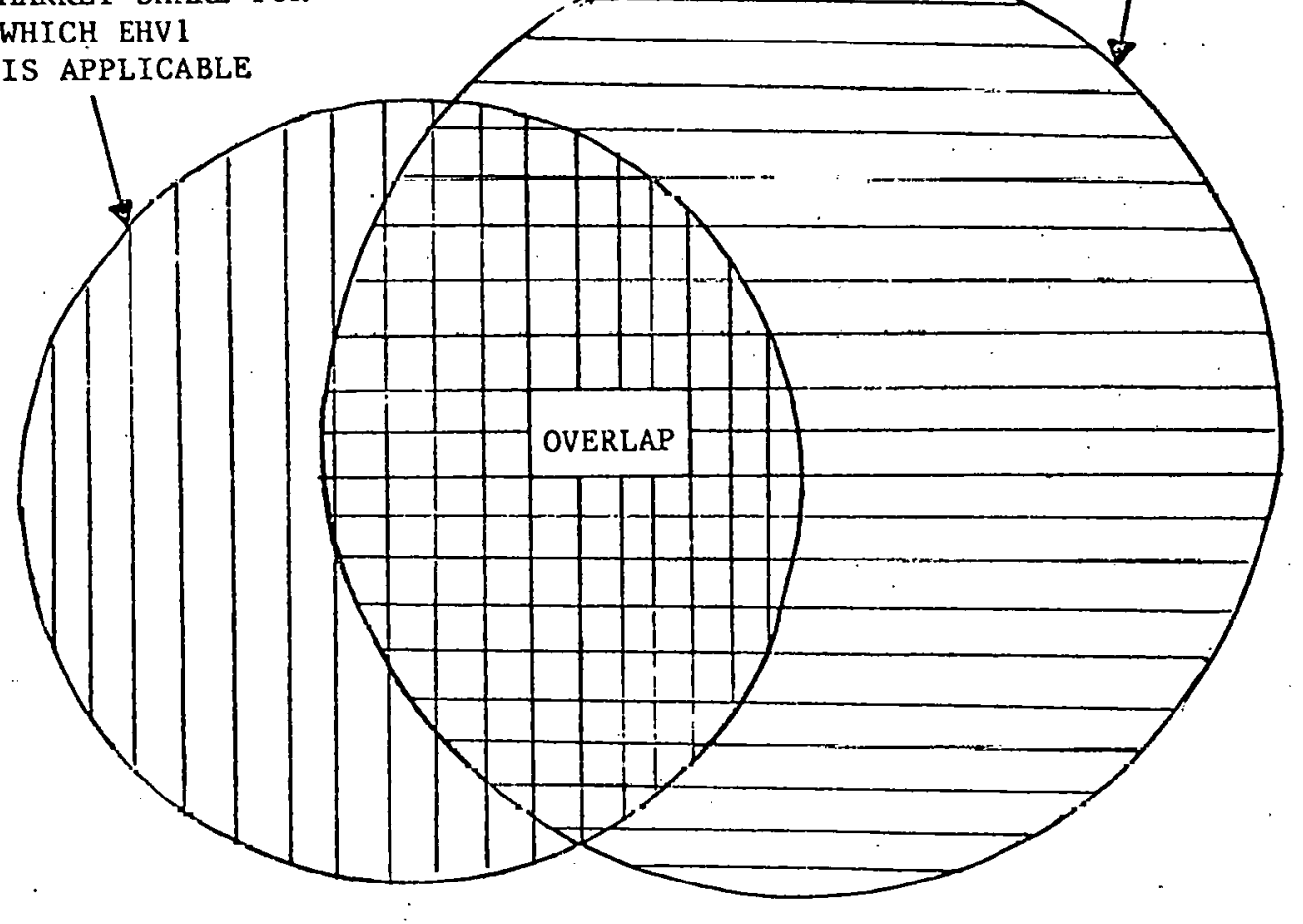

rigure 2. Illustration of Applicability Overlap Between EHV1 and EHV2 
Sampling Rates and Sectoral

Distribution of Cars ${ }^{a}$

\begin{tabular}{|c|c|c|c|c|c|c|}
\hline \multirow[b]{3}{*}{ Sector } & \multicolumn{3}{|c|}{$\begin{array}{l}\text { U.S. cars in } \\
\text { Fleets of } 10 \text { or } \\
\text { more }(000 \mathrm{~s})\end{array}$} & \multicolumn{3}{|c|}{ NAFA sample } \\
\hline & \multicolumn{3}{|c|}{ Annual Sales (1979) } & \multirow[b]{2}{*}{$\begin{array}{l}\text { Number. } \\
\text { of } f \text { leets }\end{array}$} & \multirow[b]{2}{*}{$\begin{array}{l}\text { Number } \\
\text { of cars }\end{array}$} & \multirow[b]{2}{*}{$\begin{array}{l}\text { Sampling } \\
\text { rate, }\end{array}$} \\
\hline & Stock & $\begin{array}{l}\text { Turnover } \\
\text { method }\end{array}$ & $\begin{array}{l}\text { Modifled } \\
\text { Bobit } \\
\text { estimate }\end{array}$ & & & \\
\hline BUSINESS & 3174 & 1440 & 895 & 111 & 64717 & 2.0 \\
\hline UTILITIES & 529 & 90 & 56 & 7 & 1028 & 0.2 \\
\hline POLICE & 291 & 140 & 87 & 7 & 5068 & 1.7 \\
\hline GOV'T & 645 & 160 & 99 & 17 & 13746 & 2.1 \\
\hline TOTAL & 4639 & 1830 & 1137 & 142 & 84559 & 1.8 \\
\hline \multicolumn{7}{|c|}{ TAXI, RENTAL, } \\
\hline $\begin{array}{l}\text { GRAND } \\
\text { TOTAL }\end{array}$ & 5407 & 2210 & 1373 & & & : \\
\hline$a_{F 6}$. & & & & & & \\
\hline
\end{tabular}

The second output table contains the fleet market penetration rates for the competing technologies. The values in Table $B$ are arrived at by examining the instances in shich the EHVs were applicable to a particular respondent and in those instances calculating the present value of lifecycle costs for the EHVs and comparable ICEs. The respondent is then assumed to purchase the vehicle whose life-cycle costs have the lowest present value, except in cases where vehicle purchase prices exceed limits determined by the respondent. Note that the total EHV penetration is completely divided between EHV1 and EHV2, with no overlap permitted. In situations where the EHVs overlap in terms of applicability, and in which their costs are identical and lower than those of comparable ICEs, the market portion is arbitrarily assumed to be split evenly between EHVl and EHV2. The market share won by ICEs is subdivided into a portion for which EHVs were applicable but too costly and a portion for which EHVs were nonapplicable. 
Note that a sector with non-zero entries in the ICE applicable column ( $4^{\text {th }}$ column) should have a Table $D$ of interest.

The third output table translates the market penetration rates into annual sales figures, under the assumption that fleet sales are equal to the modified Bobit estimate for 1979 (Table 3). The format for sales output is shown in Table $C$. The logic for calculating the demand reduction is covered in BNL $51312 .{ }^{\mathrm{F}} 6$

The final set of CPEN outputs show the present value of the discounted life-cycle costs perceived by fleet operators for whom EHVI or EHV2 was applicable but too expensive. The purpose of the output is to assist the GPFN nser in identifying the coot components Llial prevent an EHV from penetrating the market to the full extent permitted by its applicability. This in turn permits the CPEN user to more quickly devise subsidy prograins and other policy initiatives that would change the relative cost of an EHV, and thereby change EHV penetration. The output format is shown in Table D.1. One such table is produced for each market sector and one for all four sectors combined. In the event that EHVl is purchased in every instance where it is applicable, the two columns on the left would be irrelevant and only zeros would be displayed. The same is true for EHV2 with respect to the two columns on the right.. The battery: cost for a particular EHV could show up as $* * * * *$. This would indicate that the car has either a very short range and the battery is belng overworked, or that the car has a small battery lifecycle. Usually, a combination of both factors is responsible.

C. Program Constants

Looking at the complete program listing of CPEN, one recognizes numerous constant terms that assist in output calculations. The derivations of the constants are discussed in BNL 51312.F6

\section{APPT.TCATION INFORMATION}

At a teletype terminal, the user can dial into the computer and connect the phone to an acoustic coupler. A high-pitched tone indicates that the line between the terminal and the computer is free for use, although it does not necessarily mean that the computer software prograins are in operation. At BNL, to achieve proper communications between a terminal and the computer, one must establish software communications 


$$
\text { .. Table D.1 .. (Business Sector) }
$$

Present: value of life-cycle costs, as perceived by ICE buyers who could have purchased an EHV (that is, EHV was applicable bùt either its purchase price or its discounted life-cycle costs were too high)

MARCH 1979 DOLLARS

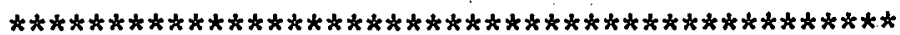
ICE BUYERS WHO COULD ICE BUYERS WHO COULD HAVE PURCHASED EHV1 HAVE PURCHASED EHV2

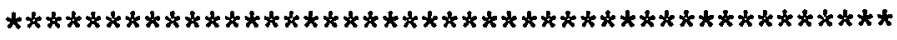
EHV1 ICE EHV2 ICE

VEHICLE

$\operatorname{COST}(W / O$ SUBSIDY)

8000.

5975.

0.

0 .

RESALE VALUE

2534.

1895.

0 .

NET DEPRECIATION

5466.

4080.

0.

0 .

\section{BATTERY}

$\operatorname{COST}(W / 0$ SUBSIDY) 1300.

411.

$0 . \quad 0$.

0 .

SALVAGE

NET DEPRECIATION

889.

0 .

0 .

0 .

0 .

0.

0 .

TOTAL VEH. \& BAT.

6355.

4080 .

0.

0 .

OPERATING 7 MAINTENANCE

$$
\begin{aligned}
& \text { FUEL } \\
& \text { ROAD TAX } \\
& \text { OTHER FIXED } \\
& \text { OTHER, VARIABLE }
\end{aligned}
$$

TOTAL $O \& M$

GROSS

LESS: SUBSIDY

LESS: WARRANTY

NET DISCOUNTED

LIFE-CYCLE COSTS

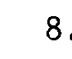

276.

828.

626.

1738 .

8093.

0 .

1513.

6580 .
2462.

0.

0 .

0 .

0 .

0 .

0.

8153.

0.

0.

0.

0.

8153.
0 .

0 .

0 .

0 .

0 .

0.

0.

0 .
0. 
with INTERCOM by entering a LOGIN command. The job-stream analysis will vary with other systems, and the user must make the proper adjustments in order to run successfully on his own system. (See Figure 3, Flowchart of Application.) LOGIN follows the pattern: LOGIN, USERNAME, PASSWORD, ACCOUNT NUMBER. A typical example is as follows:

PLEASE LOGIN

LOGIN, WEIL, DALLAS, XXXX, SUP F7

After a successful LOGIN, the word COMMAND is displayed. The user is now ready to enter the EDITOR mode of INTERCOM by typing EDITOR, that is, the computer and user would have cogether produced:

$$
\text { COMMAND - EDITOR }
$$

Editor calls facilities that create and edit files. Once in editor (two dots indicate that the user is in the edicor mode), the user can indicate that he or she is using a wide-carriage terminal by typing the command SCREEN, 132 (this can be called on the DASI 360 interactive terminal deck writer, but not on the small screen DASI 735), e.g.,

$$
\text { . . SCREEN, } 132
$$

More computer time can be requested by typing ETL 500, which will give the maximum time limit, e.g.,

$$
\text { ..ETL, } 500
$$

The wide-screen and extra-time requests will depend upon the terminal, account, and system used.

At this point the user is ready to attach the NAFA data lape (MATRIX2). The permanent filename of MATRIX2 is arbitrary, but to establish proper linkage with CPEN the local filename must be entered as TAPE2. The syntax to attach any file at BNL is: ATTACH,LOCAL filename, PERMANENT filename, ID=NAME. We attach MATRIX2 by:

$$
\text { .. ATTAC.H, TAPF.?, MATRTX7., TD=WAGNF.R. }
$$

If proper attachment of a file has been made, the following will appear (the cycle number could vary):

PE CYCLE NO. $=001$ 


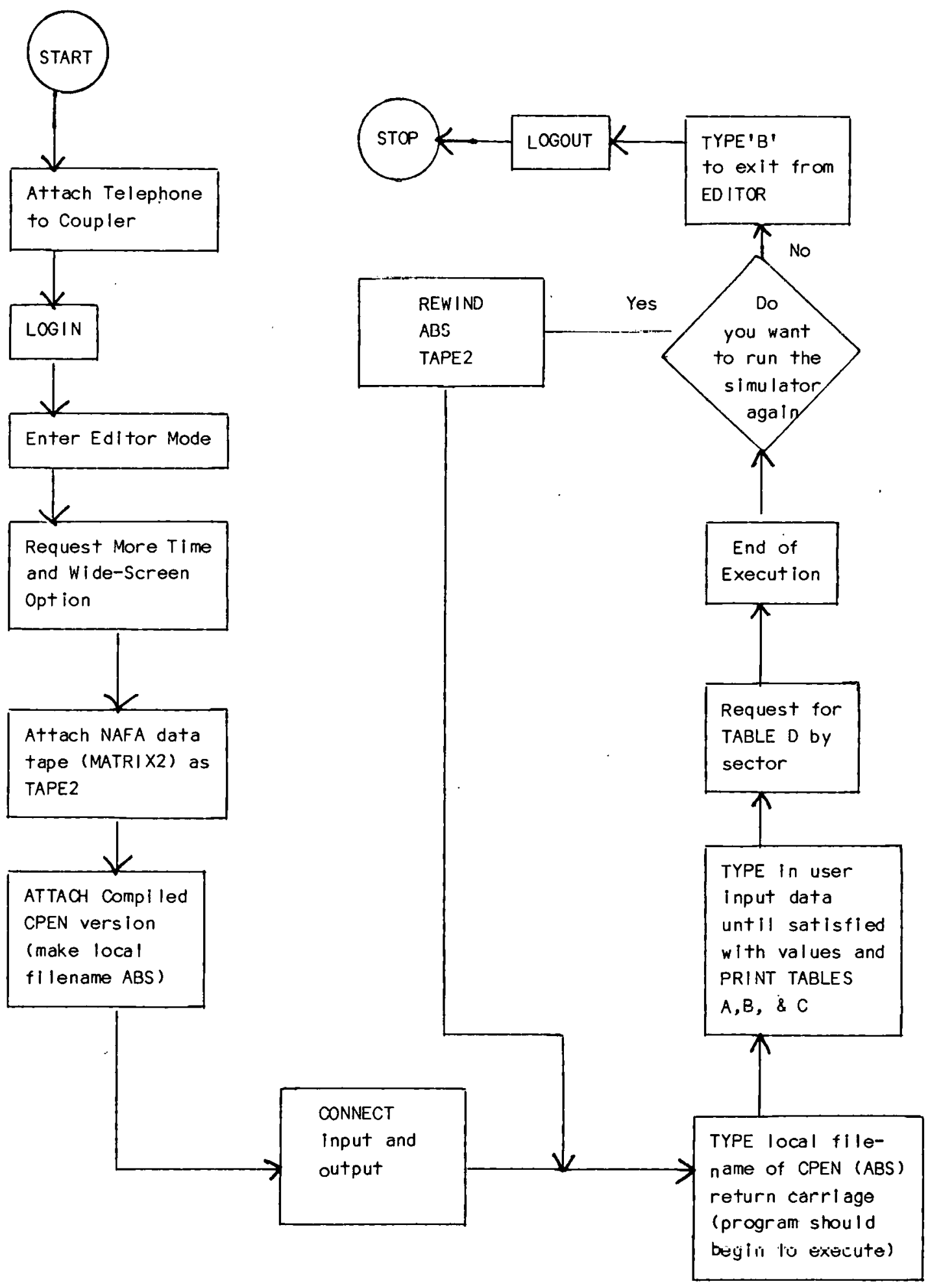

Figure 3. Flowchart of Application (Compiled Version) 
The already compiled CPEN program (absolute binary) must be attached by the command:

$$
\text { . ATTACH, ABS, CPENIABS, ID=WAGNER }
$$

Again, PF CYCLE NO. = 001 must appear. In CPEN, TAPE5 is the input tape which is read interactively. In order for the program to access the data, CONNECT, INPUT must be entered. Similarly, TAPE3, the output tape, must also be connected to the terminal by typing CONNECT,OUTPUT. Then, by typing the local filename CPENIABS (which is ABS) and returning the carriage, the program will begin to execute, e.g.,

BROOKHAVEN INTERCOM 4.5

DATE $07 / 16 / 80$

TIME 13.15.05.

PLEASE LOGIN

LOGIN, WEIL, DALLAS , 1074 , SUP

P1 NMWEIL

PNO01074

COMMAND - EDITOR

. . SCREEN, 132

. ETL, 500

-. ATTACH, TAPE2, MATRIX2, ID=WAGNER

PF CYCLE NO. $=001$

.. ATTACH, ABS, CPENIABS, $1 \mathrm{H}$ =WAGNEK

$\mathrm{PF}$ CYCLE NO. $=001$

.. CONNECT, INPUT

. . CONNECT, OIJTPIJT

..ABS

When a program change is necessary, the user will want to execute the noncompiled version as a test run. The same procedure is used up to the point where CPEN is attached. For example:

DATE $07 / 24 / 80$

TIME 14.31 .14

PLEASE LOGIN

LOGIN, WE IL, DALLAS, 1074 , SUP 


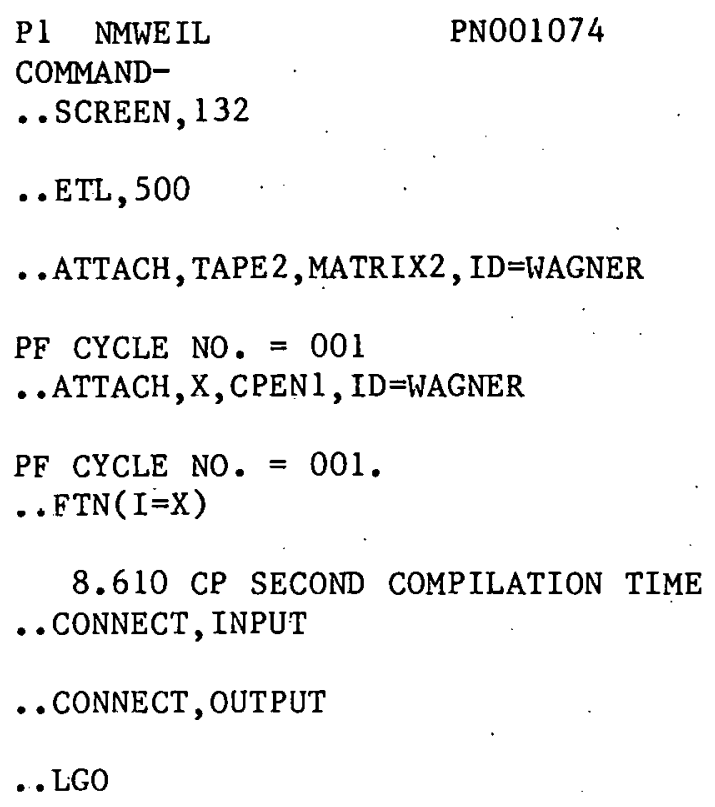

After 'CPEN1' is attached (the noncompiled version), the user must compile the program by typing FTN $(I=X)$, where $X$ is the local filename of CPENl. Then the input and, oftput files need to be connected. Finally, execute the program by the command LGO.

The execution begins with the following statement:

THIS IS THE FORTRAN DUAL SIMULATOR FOR CARS USING THE DATA COLLECTED FROM NAFA, YOU WILL INTERACTIVELY PUT IN THE ATTRIBUTES FOR TWO CARS AND THEY WILL BE RUN THROUGH THE SIMULATOR. IF YOU ARE CAPABLE OF PUTTING IN THE USER INPUTS IN A STRING OF NUMBER WITHOUT THE QUESTIONS, TYPE (1) IF YOU WANT THE QUESTIONS TELLING YOU WHAT ATTRIBUTES TO PUT IN, TYPE (2).

Immediately, the program offers two alternative paths. One path allows the user to input 10 variables simultaneously (TYPE 1). The second path asks questions for each variable entered (TYPE 2). Type 1 is faster although the user must know the sequence of data inputs. (See Appendix B.) After typing 1, the following statement appears: PLEASE PUT IN THE FIRST SET OF VARIABLES FOR THE FIRST CAR (EHVI) 10 ATTRIBUTES.

The user would then type in his physical attribute data and return the carr1age: e.g., $4,16,1,4,200,1,1,1,1,13$ F8

The next statement is for EHV2:

PLEASE PUT IN THE FIRST SET OF VARIABLES FOR THE SECOND CAR (EHV2) 10 ATTRIBUTES. 
The user then types in his data: e.g., $5,20,1,4,500,1,0,1,1,0$

A display of the 20 variables appears and the user can check for incorrect values in the first set of data (see Table 4). The program then asks the following:

IF YOU ARE SATISFIED WITH THE VARIABLES AND WANT TO CONTINUE TYPE (1)

IF YOU WANT TO CHANGE ANY ONE OR ALL OF THE VARIABLES TYPE (2)

Typing 2 returns the user to the beginning of the program where the first set of inputs were entered. The whole set of data will need to be retyped. Typing 1 sets up the program for the insertion of the second set of data. The next statement is then:

PLEASE PUT IN THE SECOND SET OF VARIABLES FOR "EHVI", 10 ATTRIDUTE3

The user would then type in his data for EHVl: e.g., $1,8000,0,1, .8,100000,500,900,200,1300^{\mathrm{F} 8}$

And for EHV 2:

PLEASE PUT IN THE SECOND SET OF VARIABLES FOR "EHV2", 10 ATTRIBUTES.

For example, $1,200,0,0, .8,1000000,450,800,500,1500$

The following statement then appears:

PLEASE PUT IN THE FUEL PRICE AND ICE VARIABLES, ' 8 ' VARIABLES

The user now typcs in the fuel prices, the ICE mpg, and the ICE prires for his oaces: c.5., 1.53,.05,25,20,17,5500,6000,6500 FR

A display of the last 28 variables input is printed (Table 5) and the user is asked to type 1 if the values are correct and to type 2 if any one or all of the values are incorrect. Typing 2 allows the user to retype the whole second set of data. Typing 1 will then print out Tables $A, B$, and C. Appendix D contains a complete execution of this Type 1 method (path) of variable entry.

IF YOU ARF, SATTSFTFI WITH THE USER INPUT DATA, NID WANT TO GENERATE THE I.C.E. COMPARISON TABLES, THEN TYPE (1) IF YOU WANT TO CHANGE ANY ONE OR ALL OF THE VARIABLES TYPE (2) 1

The second path asks the user a question for each variable entered, (Type 2 at first pause in program.) 


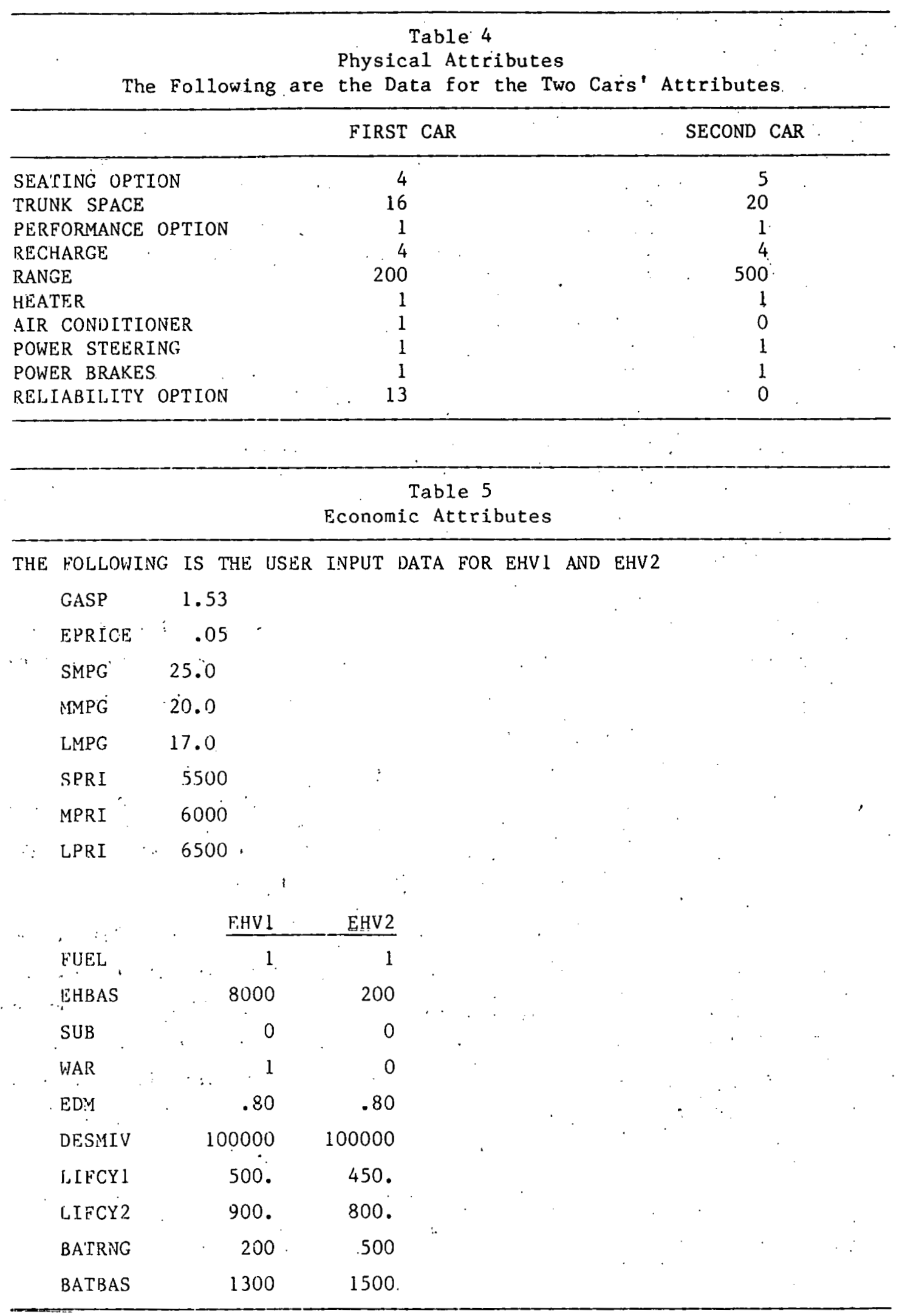


IF YOU ARE SATISFIED WITH THE USER INPUT DATA, AND WANT TO GENERATE THE I.C.E. COMPARISON TABLES, THEN TYPE (1).

IF YOU WANT TO CHANGE ANY ONE OR ALL OF THE VARIABLES TYPE (2).

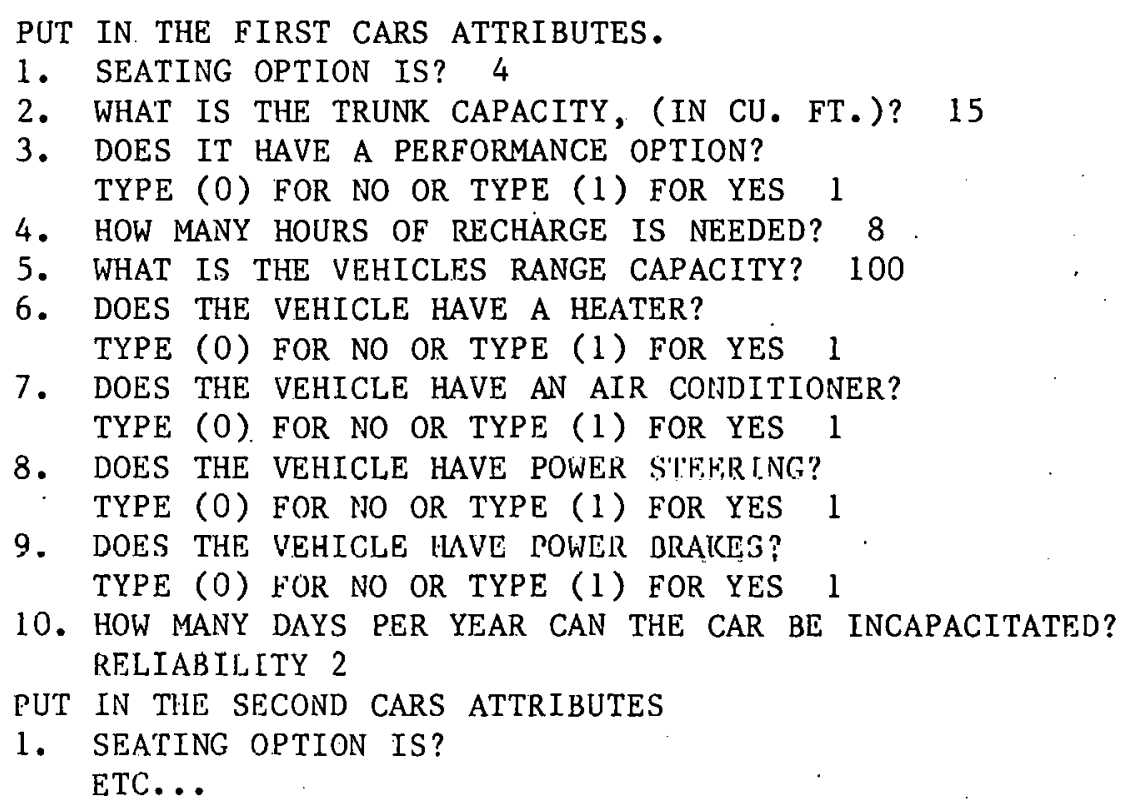

The variables are entered in the same order as the first path (See Appen$\operatorname{dix} B)$. After the first 20 variables are inserted, the program will print Table 2. The user then types 1 if all the values are correct, and 2 if any corrections need to be made.

Typing 1 will print the following:

- PLEASF INSERT USER INPUT DATA TOR TEST VELICLES TO BE USED IN THE TABULATIONS FOR THE I.C.E. COMPARISON STUDY.

-IF YOU WANT THE USER INPUT VARIABLE LIBRARY WHICH HAS A. DESCRIPTION OF EACH

-TYPE (0) FOR NO OR TYPE (1) FOR YES

The variable library is not currently completed. Fither by typing 1 or 0 the program will continue although the only difference in typing 1 i.s that a IIne wlil appear saying, $10 \mathrm{BE}$ CONTINUED... At some point in the future a variable library can be added for the user's benefit.

As with the first path, after the last 28 variahles are entered the user is asked to check the values before executing the output. Appendix E illustrates a complete execution of the second path. 
After Tables A, B, and $C$ are printed (whether for the $1^{\text {st }}$ or $2^{\text {nd }}$ path), the user is asked if he would like Table D.X $(X=1, \ldots, 5)$ printed. There is one table for each market sector and one table for all sectors combined. The following will appear next:

DO YOU WANT TO PRINT THE FOLLOWING TABLES?

-. TABLE D. l.. (BUSINESS SECTOR)

TYPE (0) FOR NO OR TYPE (1) FOR YES

Typing 1 will result in a print out of Table D.1.F9 The simulator will then ask the user if Table $D$ for the other should be printed. The message STOP indicates the end of the execution and will return the terminal into the editor mode.

DO YOU WANT TO PRINT THE FOLLOWING TABLES?

. TABLE:D.2 .. (UTILITIES SECTOR)

TYPE (0) FOR NO OR TYPE (1) FOR YES O

DO YOU WANT TO PRINT THE FOLLOWING TABLES?

. TABLE D. 3 .. (POLICE SECTOR)

TYPE (0) FOR NO OR TYPE (1) FOR YES 0

DO YOU WANT TO PRINT THE FOLLOWING TABLES?

. TABLE D. 4 .. (GOV'T SECTOR)

TYPE (0) FOR NO OR TYPE (1) FOR YES 0

DO YOU WANT TO PRINT THE FOLLOWING TABLES?

-.TABLE D.5 .. (ALL SECTORS)

TYPE (0) FOR NO OR TYPE (1) FOR YES $\underline{0}$ STOP

1.682 CP SECONDS EXECUTION TIME

Once the user is back in the editor mode, he is ready to return the simulator. There are two different restart procedures: one is for the compiled version (ABS) and the other is for the noncompiled version. In the compiled version TAPE2 and ABSF10 must be rewound. For example,

- REWIND, TAPE 2 , ABS

Now the user is ready for execution. Typing ABS will restart the simulator:

$\ldots$ ABS

In the noncompiled version, the user must rewind TAPE2 and LGO by the command:

- . REWIND, TAPE 2, LGO

and then execute it by typing LGO:

- ILGO

If the user has finished running the simulator, he must type BYE. This exits the user from editor, and the COMMAND sign should appear. Typing in LOGOUT will then disconnect INTERCOM from the terminal. 


\section{PROGRAM LISTING}

After any execution is made, batching the output file will result in the printing out of the entire CPEN program to the remote/batch station requested.

\section{IJSER ABORT}

If for any reason the user decides to abort the execution, he must do so by depressing the control button (on the terminal) and typing a $Z$ while the carriage is in motion. Then enter \%A and return the carriage. If the execution continues, repeat the process until it works. This procedure will returi the user to the editor mode.

\section{PROBLEMS \& DIAGNÜSIS}

1. Problem in LOGIN:

a) Check if coupler is properly attached

b) Check if system is operating

c) Check switches on terminal

d) Make sure account is valid

2. Insufficient Field Length:

a) Request more computer storage space.

3. $C P^{\prime}$ Tine Limit Exceeded:

a) Cheick foi: infiuile loup

b) Request more time (ETL, 500).

4. If the User Has Received Ambiguous/Wrong Results:

a) Check carefully to see if input data were correct

b) Make sure the proper data file (tape) was attarher

c) Sometimes possible noise/interference on the telephone line creates an errur, espcclally if the terminal is hooked up to the computer system from a distant location...

5. If an Arithmetic Error Appears:

a) Check to see if data tape is properly attached or rewound if already in use.

b) Check program to make sure that each array is staying within confines of its dimension.

c) Make sure no values are being divided by a zero value. 
6. If <ERROR, RETYPE AT THIS FIELD appears:

a) Try to find where you made the typing error in the data.

b): If you cannot: find the error point, just type in 1 values until you reach a point where you can retype in the variables for that seit. 
Wagner, Joseph R.; A Method for Estimating Technological Penetration Rates in Commercial Automobile Fleets, National. Center. for Analysis of Energy Systems, Brookhaven National Laboratory, BNL 51312, May 1980.

Control Data Corporation.

Intercom Version 4 Interactive Guide for Users for Fortran Extended, U.S. Publication No. 6049500, 1978.

Scope 2.1 User's Guide, U.S. Publication No. 60372600, 1975.

ANS 10 Subcomitee of the American Nuclear Sorifty's Stanilards Committee, National Standard Guidelines for the Documentation of Digital Com-

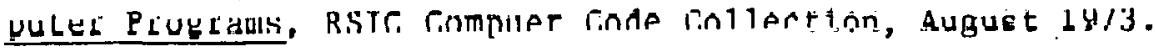


F1 - It should be emphasized, however, that there is nothing inherent in the structure of CPEN that $11 \mathrm{mits}$ it to analysis of EHVs. It can just as readily be used to examine market prospects for cars powered by sma11-displacement diesels, or for that natter, by rubber bands. All that is required is that the technology in question be characterized in terms of 1 ts physical capabilities and costs.

F2 - The base car has the following attributes: 2 seats, $5-f^{3}$ trunk $^{3}$ space, 8-hr. recharge, 30-mile range, 20-day rellability and no performance, heater, $\mathrm{A} / \mathrm{C}, \mathrm{P} / \mathrm{B}$, or $\mathrm{P} / \mathrm{S}$ options.

F3 - INTERCOM is the job control language (JCL) used to interactively access the computer (CDC 6600) at BNL.

F4 - Sinall, Medium, and Large cars are defined as follows:

$$
\begin{aligned}
& \text { small } \leq 4 \text { seats } \\
& \text { medium }=5 \text { seats } \\
& \text { large } \geq 6 \text { seats }
\end{aligned}
$$

. 5 - Conversion Table

Dollar Amounts are In March 1979 dollars. Use the following price index to convert from other year dollars:

$\begin{array}{ll}\frac{\text { YEAR }}{1972} & \frac{\text { INDEX }}{100} \\ 1977 & 141.7 \\ 1978 & 152.1 \\ 1979 & 161.4\end{array}$

F6 - Wagner, Joseph R., A Method for Estimating Technological Penetration Rates in Commercial Automobile Fleets, BNL 51312, May 1980.

F7 - At BNL, "sup" tel1s the system to suppress long system messages upon LOGIN.

F8 - The user must separate input values with either a comma or a space. The data used in the example are in Appendix C.

F9 - The purpose of the output is to assist the CPEN user in identifying the cost components that prevent an EHV from penetrating the market to the full extent permitted by its applicability. The table will be of use when a non-zero entry is in the 4 th column of Table $B$ for a particular sector. 


\section{REFERENCES Contd}

F10- ABS is the Iocal filename attached to the compiled CPEN version. It is also a coding method that tells a typical programmer that the program is already compiled (e.g., CPEN1ABS is name of compiled CPEN). 
APPENDIX A

$-27-$ 


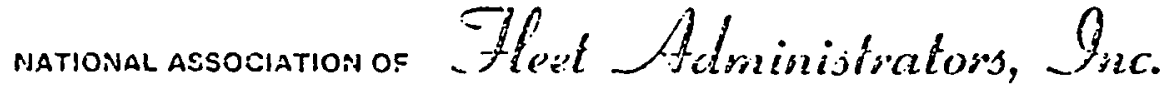

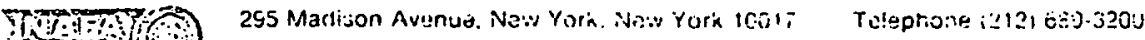

- To: $\quad$ nll NaFA Members

From: R.L. Breault, President

Re: ELECTRIC VEHICLE SURVEY

Once popular, now scorned, will electric cars return to the Ameriran highway?

In view of the ever-rising price of gasoline, the unreliability of imported supplies, the impact of emission controls, a great deal of rescarch is leing devoted to a mosible robirth of the eleclic car and lighe truck as a potential vehicle of the future.

NAFA Members - - as professional, rational car and truck buyers and lessees - - can make an important contribution to this research in one very specific area:

\section{HOI LARGE IS THE POTENTIAL MARKET FOR ELECTRIC VEHICLES?}

The enclosed survey is designed to develop answers to that question. lic urge your cooperation in carefully studying the options offered, comparing them with your transportation needs and then coapleting the questionnairc.

In addition, we are taking thls opportunity to gather information about NAFA members in a previously unknown area - - where your cars and liglit trucks are locatcd. The first shcet of the survey asks you to specify the state in which your vehicles are registered.

Th1s information will be of great help to us in developing additional data about the impact of fleets on the total vehicle market, an area much overlooked by many research organizations.

As always, your cooperation and assistance are greatly appreciated. 


\section{NUMBER OF VEIIICLES PER STATE}

(If a given vehicle operates in more than one state, assign it only to the state which serves as the vehicle ${ }^{\circ}$ base of operations.)

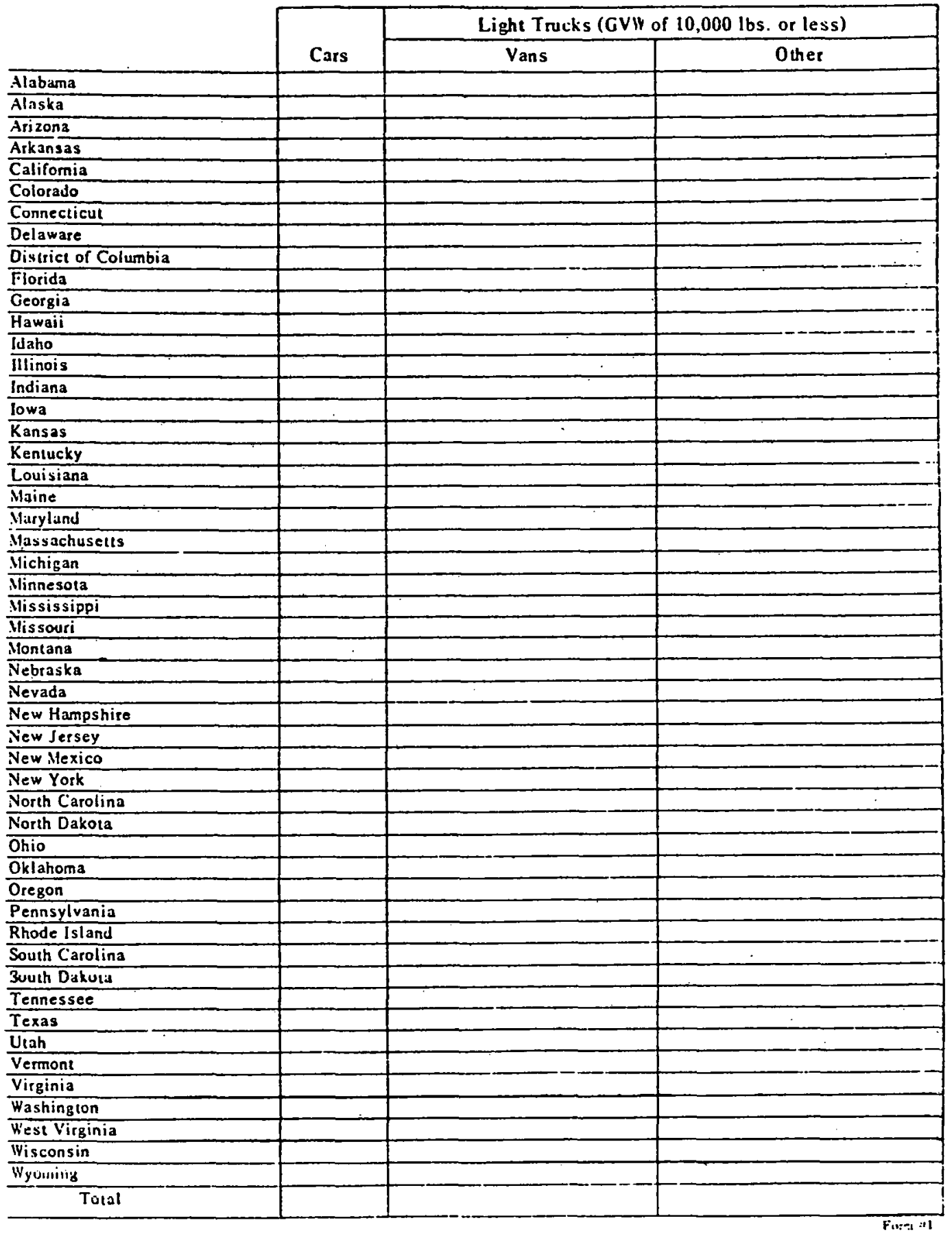




\section{INAFA(@}

NATIONAL ASSOCIATION OF FLEET ADMINISTRATORS, INC.

295 Madison Avenue, Now York, NY 10017

Name

Title

Company

\section{ELECTRIC CAR SURVEY}

Suppose thet you must replaci your cars and that the only replacements you can obtain are electric cars. The basic electric car available to you has a delivered price of $\$ 6000$. Options are available to increase the capabilities of this vehicle. All of the cars ordered do not have to have the same options. In fact, you may order as many as three different types of optional vehicles. In the table below please specify the type(s) of optional car(s) you would orde? and the price you would be willing to pay for each option. Aside from the oprional characteristics shown in the table, assume that the electric car is identical to the average cist you now operate. In the event that you prefer to lease vehicles, fill out the form with purchase price data and assume that your lease payments would reflect selling prices in the same manner as at present.

\begin{tabular}{|c|c|c|c|c|c|}
\hline & & $\begin{array}{l}\text { Base } \\
\text { Car }\end{array}$ & $\begin{array}{l}\text { Optional } \\
\text { Car \#1 }\end{array}$ & $\begin{array}{c}\text { Optional } \\
\text { Car \#2 }\end{array}$ & $\begin{array}{l}\text { Oprional } \\
\text { Car \#3 }\end{array}$ \\
\hline \multirow[t]{2}{*}{1.} & $\begin{array}{l}\text { Seating Option: } \\
\text { Seating capacity de- } \\
\text { sired (fill in number, } \\
\text { including driver) }\end{array}$ & 2 adules & $\longrightarrow$ adules & _adults & _adults \\
\hline & $\begin{array}{l}\text { Maximum price you } \\
\text { would be willing to pay } \\
\text { for this option. }\end{array}$ & KA & $\$$ & $\$$ & $\$$ \\
\hline \multirow[t]{2}{*}{2.} & $\begin{array}{l}\text { Irunk Uption: } \\
\text { Trunk spaec desired }\end{array}$ & 5 eubie fect & $\begin{array}{c}\text { cubic } \\
\text { fect }\end{array}$ & $\begin{array}{c}\text { cubic } \\
\text { feet }\end{array}$ & $\begin{array}{l}\text { cubic } \\
\text { fest }\end{array}$ \\
\hline & $\begin{array}{l}\text { Maximum price you } \\
\text { would be willing to pay } \\
\text { for this option. }\end{array}$ & (6) & 3 & 3 & $s$ \\
\hline \multirow[t]{2}{*}{3.} & $\begin{array}{l}\text { Performance Option: } \\
\text { Speed \& acceleration } \\
\text { sufficient to use } \\
\text { limiredacress ronds } \\
\text { (i.e., interstates, ex- } \\
\text { pressways) } \\
\text { (Yes or No) } \\
\end{array}$ & No & $\begin{array}{l} \\
\square \mathrm{Yes} \\
\square \mathrm{No}\end{array}$ & $\begin{array}{l}\text { 口Yes } \\
\text { ¿No }\end{array}$ & $\begin{array}{l}\square Y e s \\
\square \text { No }\end{array}$ \\
\hline & $\begin{array}{l}\text { Maximum price you } \\
\text { would be willing to pay } \\
\text { for this option. }\end{array}$ & 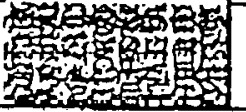 & s & 3 & s \\
\hline
\end{tabular}




\begin{tabular}{|c|c|c|c|c|c|}
\hline & & $\begin{array}{l}\text { Base } \\
\text { Car }\end{array}$ & $\begin{array}{l}\text { Optional } \\
\text { Car } \$ 1\end{array}$ & $\begin{array}{l}\text { Optional } \\
\text { Car \#2 }\end{array}$ & $\begin{array}{c}\text { Optional } \\
\text { Car } \# 3\end{array}$ \\
\hline \multirow[t]{2}{*}{4.} & $\begin{array}{l}\text { Fast Recharge Option: } \\
\text { Time needed to } \\
\text { "refuel" }\end{array}$ & 8 hours & hours & __ hours & _ hours \\
\hline & $\begin{array}{l}\text { Maximum price you } \\
\text { would be willing to pay } \\
\text { for this option. }\end{array}$ & 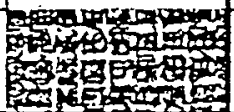 & $\$$ & 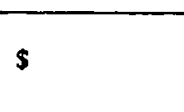 & - \\
\hline \multirow[t]{2}{*}{5.} & $\begin{array}{l}\text { Range Option: } \\
\text { Range desired be- } \\
\text { tween "refuelings" }\end{array}$ & 30 miles & _miles & _miles & _miles \\
\hline & $\begin{array}{l}\text { Maximum price you } \\
\text { would be willing to pay } \\
\text { for this option. }\end{array}$ & 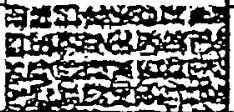 & $\$$ & $\$$ & $\$$ \\
\hline \multirow{2}{*}{6.} & $\begin{array}{l}\text { Passenger Compart- } \\
\text { ment Heater: } \\
\text { (Yes or No) }\end{array}$ & ER & $\begin{array}{l}\square \text { Yes } \\
\square \text { No }\end{array}$ & $\begin{array}{l}\square \text { Yes } \\
\square \text { No }\end{array}$ & $\begin{array}{l}\square \text { Yes } \\
\square \text { No }\end{array}$ \\
\hline & $\begin{array}{l}\text { Maximum price you } \\
\text { would be willing to pay } \\
\text { for this option. }\end{array}$ & 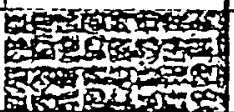 & $\$$ & $\$$ & $\$$ \\
\hline \multirow{2}{*}{7.} & $\begin{array}{l}\text { Air Conditioning: } \\
\text { (Yes or No) }\end{array}$ & No & $\begin{array}{l}\text { Yes } \\
\square \text { No }\end{array}$ & $\begin{array}{l}\text { वYes } \\
\square \text { No }\end{array}$ & $\begin{array}{l}\text { Y Yes } \\
\square \text { No }\end{array}$ \\
\hline & $\begin{array}{l}\text { Maximum price you } \\
\text { would be willing to pay } \\
\text { for this option. }\end{array}$ & 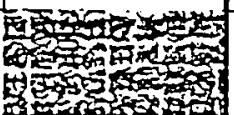 & $s$ & $s$ & $\$$ \\
\hline \multirow{2}{*}{8.} & $\begin{array}{l}\text { Power Steering: } \\
\text { (Yes or No) } \\
\end{array}$ & No & $\begin{array}{l}\text { 口Yes } \\
\square \text { No }\end{array}$ & $\begin{array}{l}\text { DYes } \\
\square \text { No }\end{array}$ & $\begin{array}{l}\text { DYes } \\
\square \text { No }\end{array}$ \\
\hline & $\begin{array}{l}\text { Maximum price you } \\
\text { would be willing to pay } \\
\text { for this option. }\end{array}$ & 30 & $\$$ & $\$$ & $\$$ \\
\hline \multirow{2}{*}{9.} & $\begin{array}{l}\text { Power Brakes: } \\
\text { (Yes or No) }\end{array}$ & No & $\begin{array}{l}\text { Yes } \\
\text { DNo }\end{array}$ & $\begin{array}{l}\square \text { Yes } \\
\square \text { No }\end{array}$ & $\begin{array}{l}\text { DYes } \\
\text { QNo }\end{array}$ \\
\hline & $\begin{array}{l}\text { Maximum price you } \\
\text { would be willing to pay } \\
\text { for this option. }\end{array}$ & 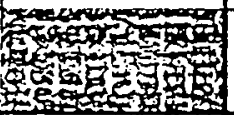 & $\$$ & $\$$ & $\$$ \\
\hline \multirow{2}{*}{10.} & $\begin{array}{l}\text { Reliability Option: } \\
\text { Allowable annual } \\
\text { number of unsched- } \\
\text { uled days in shop }\end{array}$ & 20 days & ___ days & ___ days & _days \\
\hline & $\begin{array}{l}\text { Maximum price you } \\
\text { would be willing to pay } \\
\text { for this option. }\end{array}$ & 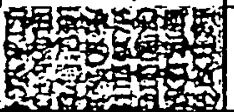 & s & $\$$ & s \\
\hline 11. & $\begin{array}{l}\text { What percentage of } \\
\text { your car fleet would } \\
\text { use each type of car? } \\
\text { (Total of this line } \\
\text { must equal } 100 \% \text { ) }\end{array}$ & z & — $\%$ & — $\%$ & — \\
\hline
\end{tabular}




\section{NAFA (2)}

NATIONAL ASSOCIATION OF FLEET ADMINISTRATORS, INC.

295 Madison Arenue, New York, NY 10017

Name

Title

Company

\section{ELECTRIC TRUCK SURVEY}

Suppose that you must replace your linht rucks (GVN of 10,000 lbs or los) and that the only replacements you can obtain are electric trucks. The basic electric truck available to you has a delivered price of $\$ 6000$. Options are available to increase the capabilities of this vehicie. All of the trucks ordered do not have to have the same options In facs, you may order as many as three different types of optional vehicles In the sable below please specify the type(s) of optional muck(s) you would order dud die price you would be willing to pay for each option. Aside from the optional characteristics shown in the table, assume that the electric track is identical to the average truck you now operate. In the event that you prefer to lease vehicles, fill out the form with purchase price data and assume that your lease payments would reflect selling prices in the same manner as at present

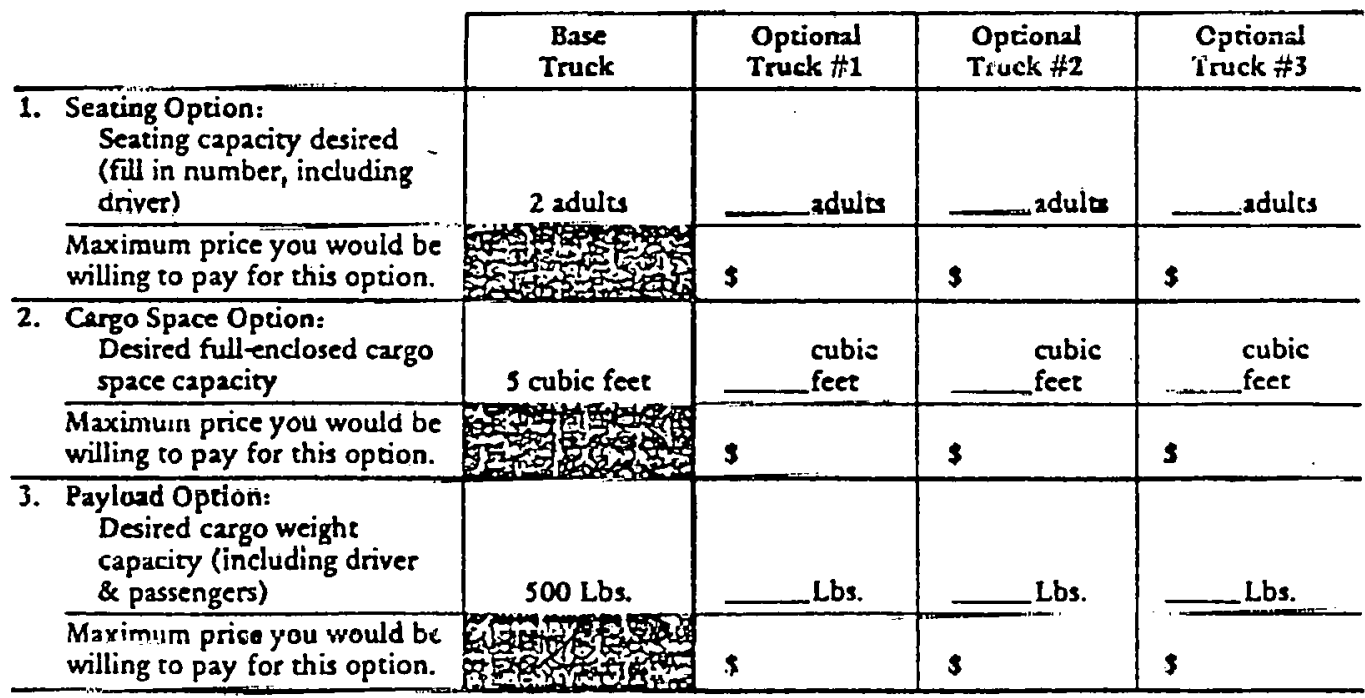




\begin{tabular}{|c|c|c|c|c|c|}
\hline & $\begin{array}{l}\text { Base } \\
\text { Truck }\end{array}$ & $\begin{array}{l}\text { Oprional } \\
\text { Truck \#1 }\end{array}$ & $\begin{array}{l}\text { Optional } \\
\text { Truck \#2 }\end{array}$ & $\begin{array}{l}\text { Optional } \\
\text { Truck \#3 }\end{array}$ \\
\hline 4. & $\begin{array}{l}\text { Performance Option: } \\
\text { Speed and acceleration suf- } \\
\text { ficient to use limited-access } \\
\text { roads (i.e., interstates, } \\
\text { expressways) } \\
\text { (Yes or No) }\end{array}$ & No & $\begin{array}{l}\square \text { Yos } \\
\square \text { No }\end{array}$ & $\begin{array}{l}\square Y_{0} \\
\square \text { No }\end{array}$ & $\begin{array}{l}\square \text { Yes } \\
\square \text { No }\end{array}$ \\
\hline & $\begin{array}{l}\text { Maximum price you would be } \\
\text { willing to pay for this option. }\end{array}$ & 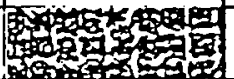 & $\$$ & $\$$ & s \\
\hline \multirow[t]{2}{*}{5.} & $\begin{array}{l}\text { Fast Recharge Option: } \\
\text { Time needed to "refuel" }\end{array}$ & 8 hours & __ hours & __hours & _._. hours \\
\hline & $\begin{array}{l}\text { Maximum price you would be } \\
\text { willing to pay for this option. }\end{array}$ & 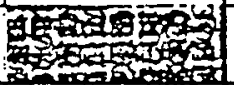 & $\$$ & $\$$ & s \\
\hline \multirow[t]{2}{*}{6.} & $\begin{array}{l}\text { Range Option: } \\
\text { Range desired between } \\
\text { "refuelings" }\end{array}$ & 30 miles & _miles & ___miles & _miles \\
\hline & $\begin{array}{l}\text { Maximum price you would be } \\
\text { willing to pay for this option. }\end{array}$ & 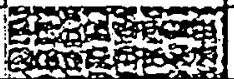 & $\$$ & $\$$ & $\$$ \\
\hline \multirow[t]{2}{*}{7.} & $\begin{array}{l}\text { Passenger Compartment } \\
\text { Heater: } \\
\text { (Yes or No) }\end{array}$ & 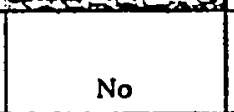 & $\begin{array}{l}\square \text { Yes } \\
\square \text { No }\end{array}$ & $\begin{array}{l}\square \text { Yes } \\
\square \text { No }\end{array}$ & $\begin{array}{l}\square \text { Yes } \\
\square \text { No }\end{array}$ \\
\hline & $\begin{array}{l}\text { Maximum price you would be } \\
\text { willing to pay for this option. }\end{array}$ & 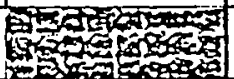 & $\mathbf{s}$ & $s$ & $\mathbf{s}$ \\
\hline \multirow{2}{*}{8.} & $\begin{array}{l}\text { Air Conditioning: } \\
\text { (Yes or No) }\end{array}$ & No & $\begin{array}{l}\text { DYes } \\
\text { व No }\end{array}$ & $\begin{array}{l}\text { DYes } \\
\text { Q No }\end{array}$ & $\begin{array}{l}\text { DYes } \\
\square \text { No }\end{array}$ \\
\hline & $\begin{array}{l}\text { Maximum price you would be } \\
\text { willing to pay for this option. }\end{array}$ & 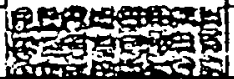 & $\$$ & $\$$ & $\$$ \\
\hline \multirow[t]{2}{*}{9.} & $\begin{array}{l}\text { Power Steering: } \\
\text { (Yes or No) }\end{array}$ & No & $\begin{array}{l}\text { QYes } \\
\square \text { No }\end{array}$ & $\begin{array}{l}\text { 口Yes } \\
\square \text { No }\end{array}$ & $\begin{array}{l}\text { Yes } \\
\square \text { No }\end{array}$ \\
\hline & $\begin{array}{l}\text { Maximum price you would be } \\
\text { willing to pay for this option. }\end{array}$ & 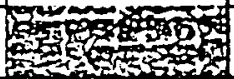 & $\$$ & $\$$ & $s$ \\
\hline \multirow[t]{2}{*}{10.} & $\begin{array}{l}\text { Power Brakes } \\
\text { (Yes or No) }\end{array}$ & No & $\begin{array}{l}\text { 口Yes } \\
\text { QNo }\end{array}$ & $\begin{array}{l}\square \text { Yes } \\
\square \text { No }\end{array}$ & $\begin{array}{l}\text { DYes } \\
\square \text { No }\end{array}$ \\
\hline & $\begin{array}{l}\text { Maximum price you would be } \\
\text { willing to pay for this option. }\end{array}$ & 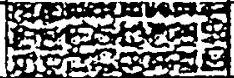 & $\$$ & $\$$ & s \\
\hline \multirow[t]{2}{*}{11.} & $\begin{array}{l}\text { Reliability Option:- } \\
\text { Allowable annual number of } \\
\text { unscheduled days in shop }\end{array}$ & 20 days & days & _days & _days \\
\hline & $\begin{array}{l}\text { Maximum price you would be } \\
\text { willing to pay for this option. }\end{array}$ & E0. & $\$$ & $\$$ & $s$ \\
\hline$\overline{12 .}$ & $\begin{array}{l}\text { What percentage of your truck } \\
\text { fleet would use each type of } \\
\text { truck? } \\
\text { (Total of this line must equal } \\
100 \% \text { ) }\end{array}$ & & — $\%$ & — & - $\%$ \\
\hline
\end{tabular}




\section{THIS PAGE \\ WAS INTENTIONALLY \\ LEFT BLANK}


APPENDIX B 
Name of Scenario:

CODE :

First Set

$\underline{\text { EHV1 }} \underline{\text { EHV2 }}$

Seats (including driver)
Trunk (in cubic feet)
Performance Option ( $Y$ or $N$ )
Recharge Time (hrs.)
Range (miles)
Heater (Y or $N$ )
Air Conditioning ( $Y$ or $N$ )
Power Steering (Y or N)
Power Brakes (Y or N)
Reliability (days)

\begin{tabular}{c|c|}
\hline 1 \\
\hline 2 \\
\hline 3 \\
\hline 4 \\
\hline 5 \\
\hline 6 \\
\hline 7 \\
\hline 8 \\
\hline 9 \\
\hline 10 \\
\hline
\end{tabular}

Second Set

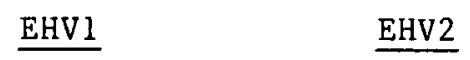

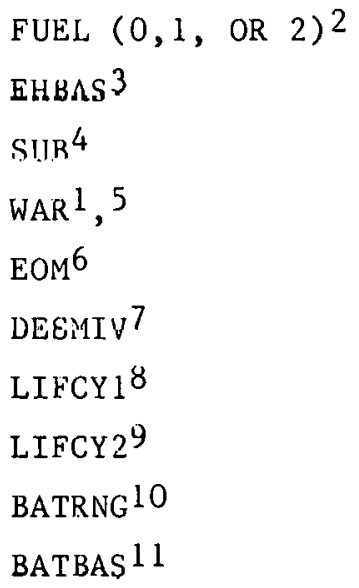

\begin{tabular}{r|}
\hline 21 \\
\hline 22 \\
\hline 24 \\
\hline 25 \\
\hline 26 \\
\hline 27 \\
\hline 28 \\
\hline 29 \\
\hline 30 \\
\hline
\end{tabular}

Fuel Price - GASP, (1iquid fuel;\$/gal) 41 EPRICE(electricity; \$/kWh) 42

ICE fuel consumption ( $\mathrm{mpg}$ ):

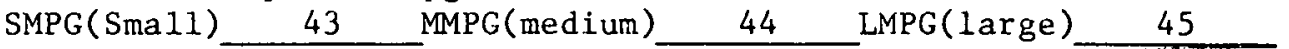

ICE prices (dollars): SPRI (sma 11) $\quad 46 \quad$ MPRI(medium) $47 \quad 47 \quad$ LPRI(large) $\quad 48$ 


\section{Footnotes for CPEN User Inputs}

1. Yes is denoted by a 1 , and No is denoted by a 0 .

2. $(0,1$, or 2$)$ respectively corresponds to (liquid, electric, or hybrid) fuel.

3. Base price (ignoring subsidy) of EHV vehicle, exclusive of battery.

4. The purchase subsidy on EHV.

5. Indicates whether EHV carries a special 3-year warranty covering: collision and liability insurance, maintenance and repairs, and a free loaner vehicle.

6. Electric vehicle monthly variable nonfuel operating and maintenance costs, as a decimal fraction of comparable ICE costs. Cost items consist of oil, tires, repair (less recoveries), maintenance, washing, and miscellaneous incidental expenses.

7. The design mileage of the EHV vehicle (i.e., vehicle lifetime in (miles), exclusive of battery lifetime.

8. The lifetime of the EHV battery, assuming that the battery is fully discharged on each cycles. Recharge cycles.

9. The lifetime of the EHV battery, assuming that the batter's average death of discharge is $65 \%$. Recharge cycles.

10. EHV range when operating on batteries only. Miles per recharge.

11. Base price (ignoring subsidy) of EHV battery. 


\section{THIS PAGE}

WAS INTENTIONALLY

LEFT BLANK 
$\therefore \quad \therefore \quad=$

APPENDIX C 


\section{CPEN User Inputs}

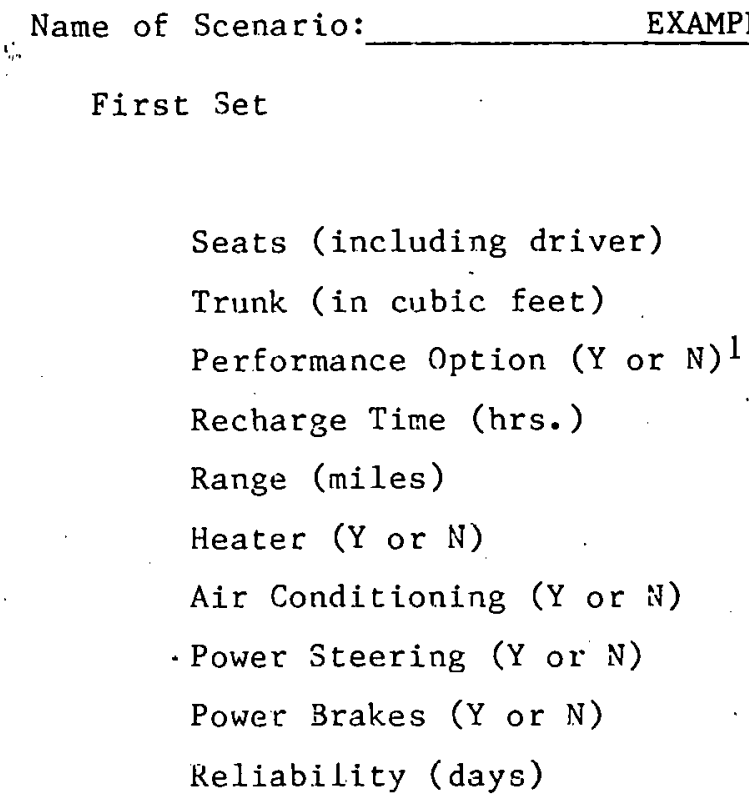

CODE :

$\underline{\text { EHV } 1}$

EHV2

\begin{tabular}{c|c}
\hline 4 \\
\hline 16 \\
\hline$y(1)$ \\
\hline 4 \\
\hline 200 \\
\hline$y(1)$ \\
\hline$y(1)$ \\
\hline$y(1)$ \\
\hline$y(1)$ \\
\hline 13 \\
\hline$y(1)$ \\
\hline$y(1)$ \\
\hline
\end{tabular}

Second Set

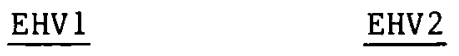

FUEL $(0,1, \text { OR } 2)^{2}$
EHBAS $^{3}$
SUD $^{4}$
WAR $^{1},^{5}$
EOM $^{6}$
DEEMIV $^{7}$
LIFCYI $^{8}$
LIFCY $^{9}$
BATRNG $^{10}$
BATBAS $^{11}$

\begin{tabular}{r|r}
\hline 1 \\
\hline 0000 \\
\hline 0 \\
\hline 1 \\
\hline .8 \\
\hline 100000 \\
\hline 500 \\
\hline 900 \\
\hline 200 \\
\hline 1300 \\
\hline
\end{tabular}

Fuel Price-GASP, (1iquid fuel; \$/ga1) 1.53 EPRICE(electricity; \$/kWh)_.05

ICE fuel consumption (mpg): SMPG(Smal1) _25 MMPG(medium) $20 \quad$ LNPG( large) 17

ICE prices (dollars): SPRI (sma11)_5500_MPRI (medium) $6000 \quad$ LPRI ( large) $\quad 6500$ 
APYEND $1 X$ D 
BROOKHAVEN INTERCOM 4.5

DATE $09 / 10 / 80$

TTMF, 1.1 .13 .29

PLEASE LOGIN

LOGIN, WEIL, DALLAS, 1.074, SUP

SUP UPDATED $09 / 08 / 80$ TODAY IS $09 / 10 / 80$

l. 1 RMWEIL

PNO01074

COMMAND-EDITOR

-. SCREEN, 132

..ETL, 500

.. ATTACH, TAPE 2, MATR IX2, ID=WAGNER

PF CYCLE NO. = 001

.. ATTACII, ABS. CPEN I ABS, ID=INAGNER

PF CYCLE NO. $=001$

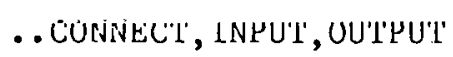

..ABS

THIS IS THE FORTRAN DUEL SIMULATOR FOR CARS USING THE DATA COLLECTED FROM NAFA, YOU WILL INTERACTIVELY PU'C IN THE ATTRIBUTES FOR TWO CARS AND THEY WILL BE RUN THROUGH THE SIMULATOR. IF YOU ARE CAPABLE OF PUTTING IN THE USER INPUTS IN A STRING OF NUMBERS WITHOUT THE QUESTIONS, TYPE (1) IF YOU 
WANT THE QUESTIONS TELLING YOU WHAT ATTRIBUTES TO PUT IN, TYPE (2) 1 PLEASE PUT IN THE FIRST SET OF VARIABLES FOR THE FIRST CAR (EHVi) '10' ATTR IBUTES $4,16,1,4,200,1,1,1,1,13$

PLEASE PU'T IN THE FIRST SET OF VARIABLES FOR THE SECOND CAR (EHV2) '10' ATTRIBUTES $5,20,1,4,500,1,0,1,1,0$

THE FOLLOWING IS THE DATA FOR TIE TWO CARS ATTRIBUTES FIRST CAR SECOND CAR

SEATING OPTION 45

TRUNK SPACE 1620

PERFORMANCE OPTION

RECHARGE

1 . 1

RANGE

4

HEATER 200 4

AIR CONDITIONER 1 500

POWER STEERING

POWER BRAKES

RELIABILITY OPTION

$\begin{array}{rl}1 & 1 \\ 1 & 0 \\ 1 & 1 \\ 13 & 1 \\ & 0\end{array}$

IF YOU ARE SATISFIED WITH THE VARIABLES AND WANT TO CONTINUE TYPE (1) IF YOU WANT TO CHANGE ANY ONE OR ALL OF THE VARIABLES TYPE (2) 1

PLEASE PUT IN THE SECOND SET OF VARIABLES FOR "EHV1", '10' ATtRIbUtes $1,8000,0,1, .8,100000,500,900,200,1300$

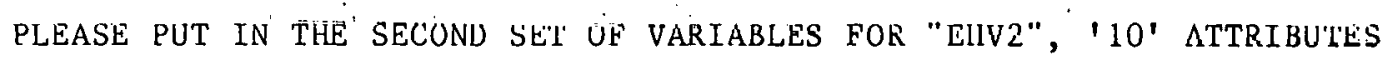
$1,200,00,00.8,100000,450,800,500,1500$

PLEASE PUT IN THE EUEL PRICE AND ICE VARIABLES, '8' VARIABLES $1.53, .05,25,20,17, .5500,6000,6500$ 
THE FOLLOWING IS THE USER INPUT DATA FOR EHV1 AND EHV2

$\begin{array}{lr}\text { GASP } & 1.53 \\ \text { EPRICE } & .05 \\ \text { SMPG } & 25.0 \\ \text { MMPG } & 20.0 \\ \text { LMPG } & 17.0 \\ \text { SPRI } & 5500 \\ \text { MPRI } & 6000 \\ \text { LPRI } & 6500\end{array}$

$\begin{array}{lrr} & \text { EHVI } & \text { F.HV? } \\ \text { FUEL } & 1 & 1 \\ \text { EIIBAS } & 8000 & 20 \pi \\ \text { SUB } & 0 & 0 \\ \text { WAR } & 1 & 0 \\ \text { EOM } & .80 & .80 \\ \text { DESMIV } & 100000 & 100000 \\ \text { LIFCY1 } & 500 . & 450 . \\ \text { LIFCY2 } & 900 . & 800 . \\ \text { BATRNG } & 200 & 500 \\ \text { BATBAS } & 1300 & 1500 .\end{array}$

IF YOU ARE GATI3FIED WITH THH, USEK INPUT DATA, AND WANT TO GENERATE THE I. E. .. CUMYAKISUN TABLES, THEN TYPE (1)

IF YOU WANT TO CHANGE ANY ONE OR ALL OF THE VARIABLES IYYPE (2) 1 
APPENDIX E 
EXAMPLE RUN

(Long Path)

... REWIND, TAPE2, ABS

$\ldots \mathrm{ABS}$

THIS IS THE FORTRAN DUEL SIMULATOR FOR CARS USING THE DATA COLLECTED FROM NAFA, YOU WILL INTERACTIVELY PUT IN THE ATTRIBUTES FOR TWO CARS AND THEY WILL BE RUN THROUGH THE SIMULATOR. IF YOU ARE CAPABLE OF PUTTING IN. THE USER INPUTS IN A STRING OF NUMBERS WITHOUT THE QUESTION, TYPE (1)

IF YOU WANT THE QUESTIUNS 'IELLING YOU WIIAT ATTRIBUTES TO PITT IN TYPE (2) 2

PUT IN THE FIRST CARS ATTRIBUTES

I. SEATING OPTION IS? 4

2. WHAT IS THE TRUNK CAPACITY, (IN CU.FT.) 16

3. DOES IT HAVE A PERFORMANCE OPTION?

TYPE (0) FOR NO OR TYPE (1) FOR YES I

4. HOW MANY HOURS OF RECHARGE IS NEEDED? 4

5. WHAT IS THE VEHILLES RANGE CACACITY? 300

6. DOES THE VEHICLE HAVE A HEATER?

TYPE (O) FOR NO OR TYPE (1) FOR YES 1

7. DOES THF VEHICLE HAVE A AIK CUNUITIONER?

TYPE (O) FOR NO OR TYPE (1) FOR YES 1

8. DOES THE VEHICLE HAVE POWER STEERING?

TYPE (0) FOR NO OR TYPE (1) FOR YES 1

9. DOES THE VEHICLE HAVE POWER BRAKES?

TYPE (0) FOR NO OR TYPE (1) FOK YES 1

10. HOW MANY DAYS PER YEAR CAN THE CAR BE INCAPACITATED? RELIABILITY 13 
PUT IN THE SECOND CARS ATTRIBUTES

1. SEATING OPTION IŚ 5

2. WHAT IS THE TRUNK CAPACITY, (IN CU.FT.) 20

3. DOES IT HAVE A PERFORMANCE OPTION?

TYPE (0) FOR NO OR TYPE (1) FOR YES 1

4. HOW MANY HOURS OF RECHARGE IS NEEDED? 4

5. WHAT IS THE VEHICLES RANGE CAPACITY? 500

6. DOES THE VEHICLE HAVE A HEATER?

TYPE (0) FOR NO OR TYPE (1) FOR YES 1

7. DOES THE VEHICLE HAVE A AIR CONDITIONER?

TYPE (0) FOR NO OR TYPE (1) FOR YES 0

8. DOES THE VEHICLE HAVE POWER STEERING?

TYPE (0) FOR NO OR TYPE (1) FOR YES 1.

9. DOES THE VEHICLE HAVE POWER BRAKES?

TYPE (0) FOR NO OR TYPE (1) FOR YES 1

10. HOW MANY DAYS PER YEAR CAN THE CAR BE INCAPACITATED? RELIABILITY O

THE FOLLOWING IS THE DATA FOR THE TWO CARS ATTRIBUTES

FIRST CAR SECOND CAR.

SEATING OPTION

45

TRUNK SPACE

PERFORMANCE OPTION

RECHARGE

1620

RANGE

1

4

1

HEATER

AIR CONDITIONER

200

4

POWER STEERING

1

500

POWER BRAKES

RELIABILITY OPTION

1
1
1
13 $\quad \begin{aligned} & 1 \\ & 1\end{aligned}$

IF YOU ARE SATISEIED WITH THE VARIABLES AND WANT TO CONTINUE TYPE (1)

IF YOU WAN'I TU CHANGE ANY ONE OR ALL OF THE VARIABLES TYPE (2) 1 
PLEASE INSERT USER INPUT DATA FOR TEST VEHICLES TO BE USED IN THE TABULATIONS FOR THE I.C.E. COMPARISON STUDY IF YOU WANT THE USER INPUT VARIABLE LIBRARY WHICH HAS A DESCRIPTION OF EACH VARIABLE TYPE (0) FOR NO OR TYPE (1) FOR YES O

PUT IN EHVI'S USER INPUT DATA

WHAT IS THE

1. FUEL, EITHER 0,1 , OR 21

2. EHBAS? 8000

3. SUB ? 0

4. WAR ? 1

5. EOM ? .8

6. DESMIV ? 100000

7A. LIFCY 1 ? 500

7R. LIFGY2 ? 900

8. BATRING ? 200

9. BATBAS ? 1300

PUT IN EHV2'S USER INPUT DATA

WHAT IS THE

1. FUEL, EITHER 0,1 , OR 21

2. EHBAS ? 200

3. SUB ? 0

4. WAR ? $\cap$

5. EOM ? .8

6. DESMIV ? 100000

7A. TITFCYI? 450

7B. LIFCY2 ? 800

8. BATRNG ? 500

9. BATBAS ? 1500

NOW PUT IN THE VARIABLF.G THAT ARE SIMILAR TO EHVI ȦNU EHV2 WHAT IS THE

1. CASP ? 1.53

2. E.PRICE ?.05

3. SMPG ? 25

4. MMPG ? 20

5. LMPG ? 17

6. SPRI ? 5500

7. MPRI ? 600

8. LPRI ? 6500 
THE FOLLOWING IS THE USER INPUT DATA FOR EHVI AND EHV2

$\begin{array}{lr}\text { GASP } & 1.53 \\ \text { EPRICE } & .05 \\ \text { SMPG } & 25.0 \\ \text { MMPG } & 20.0 \\ \text { LMPG } & 17.0 \\ \text { SPRI } & 5500 \\ \text { MPRI } & 6000 \\ \text { LPRI } & 6500\end{array}$

$\begin{array}{lrr} & \text { EHV1 } & \text { EHV2 } \\ \text { FUEL } & 1 & 1 \\ \text { EHBAS } & 8000 & 200 \\ \text { SUB } & 0 & 0 \\ \text { WAR } & 1 & 0 \\ \text { EOM } & .80 & .80 \\ \text { DESMIV } & 100000 & 100000 \\ \text { LIFCY 1 } & 500 . & 450 . \\ \text { LIFCY2 } & 900 . & 800 . \\ \text { BATRNG } & 200 & 500 \\ \text { BATBAS } & 1300 & 1500\end{array}$

IF YOU ARE SATISEIED WITH THE USER INPUT DATA, AND WANT TO GENERATE THE I. C.E. COMPARISON TABLES, THEN TYPE (1)

IF YOU WANT TO CHANGE ANY ONE OR ALL OF THE VARIABLES TYPE (2) 1 


\section{THIS PAGE}

WAS INTENTIONALLY

LEFT BLANK 
APPENDIX F 
TABLE A

Applicability Rates (Percent)

\begin{tabular}{lrrrr}
\hline SECTOR & EHV1 & EHV2 & OVERLAP & $\begin{array}{r}\text { TOTAL } \\
\text { EHV }\end{array}$ \\
\hline BUSINESS & 19. & 13. & 8. & 24. \\
UTILITIES & 49. & 43. & 33. & 59. \\
POLICE & 5. & 1. & 1. & 5. \\
GOV'T & 25. & 28. & 24. & 29. \\
\multicolumn{1}{c}{ TOTAL } & 22. & 18. & 12. & 28. \\
\hline
\end{tabular}

TABLE B

Fleet Car Penetration Rates (Percent)

\begin{tabular}{lcrrrrrr}
\hline & $* * * * * * * * *$ & EHV & $* * * * * * * * * *$ & $* * * * * * * * * * * * * * * *$ \\
NON- & ICE & $* * * * * * * * * * * * * * * * *$ \\
SECTOR & EHV1 & EHV2 & TOTAL & APPLICABLE & APPLICABLE & TOTAL & TOTAL \\
\hline BUSINESS & $.0 \%$ & $6.1 \%$ & $6.2 \%$ & $3.7 \%$ & $90.1 \%$ & $93.8 \%$ & $100.0 \%$ \\
UTILITIES & $0.0 \%$ & $31.4 \%$ & $31.4 \%$ & $0.0 \%$ & $68.6 \%$ & $68.6 \%$ & $100.0 \%$ \\
POLICE & $0.0 \%$ & $.3 \%$ & $.3 \%$ & $.3 \%$ & $99.5 \%$ & $99.7 \%$ & $100.0 \%$ \\
GOV'T & $0.0 \%$ & $28.5 \%$ & $28.5 \%$ & $8.6 \%$ & $63.0 \%$ & $71.5 \%$ & $100.0 \%$ \\
TOTAL & $.0 \%$ & $1.1 .7 \%$ & $11.8 \%$ & $3.8 \%$ & $84.5 \%$ & $88.2 \%$ & 100.0 \\
\hline
\end{tabular}

Fleet Car Annual Sales (Thousands)

\begin{tabular}{|c|c|c|c|c|c|c|c|}
\hline \multirow[b]{2}{*}{ SEC'TOR } & \multirow{2}{*}{ EHV1 } & \multirow{2}{*}{$\begin{array}{l}\text { EHV } \\
\text { EHV2 }\end{array}$} & \multirow{2}{*}{$\begin{array}{l}* * * * * * * * \\
\text { TOTAL }\end{array}$} & \multirow[b]{2}{*}{ ICE } & \multirow[b]{2}{*}{ TOTAL } & \multicolumn{2}{|c|}{$\begin{array}{l}\text { ADJUSTMENTS FOR PRICE- } \\
\text { INDUCED DEMAND REDUCTION } \\
* * * * * * * * * * * * * * * * * * * * *\end{array}$} \\
\hline & & & & & & $\begin{array}{l}\text { DEMAND } \\
\text { REDUCTION }\end{array}$ & $\begin{array}{l}\text { ORIGINAL } \\
\text { DEMAND }\end{array}$ \\
\hline BUSINESS & 0. & 24. & 24. & 360. & 384. & 511. & 895. \\
\hline UTILITIES & 0. & 3. & 3. & 7. & 10. & 46. & 56. \\
\hline POLICE & 0. & 0. & 0. & 66. & 66. & 21 . & 87. \\
\hline GOV'T & 0. & 6. & 6. & 14. & 20. & 79. & 99. \\
\hline TOTAL & 0. & 33. & 33. & 448 & 480 & 657 . & 1137. \\
\hline
\end{tabular}


DO YOU WANT TO PRINT THE FOLLOWING TABLES?

..TABLE D.1...(BUSINESS SECTOR)

TYPE (0) FOR NO OR TYPE (1) FOR YES 1 .

\section{..TABLE D. 1 .. (BUSINESS SECTOR)}

PRESENT VALUE OF LIVE-CYCLE COSTS, AS PERCEIVED BY ICE BUYERS WHO COULD HAVE PURCHASED AN EHV (THAT IS, EHV WAS APPLICABLE BUT EITHER ITS PURCHASE PRICE WAS TOO HIGH OR IT'S DISCOUNTED LIFE-CYCLE COSTS WERE TOO HIGH)

\begin{tabular}{|c|c|c|c|c|}
\hline & \multicolumn{4}{|c|}{$\begin{array}{c}\text { MARCH } 1979 \text { DOLLARS } \\
\star * * * * * * * * * * * * * * * * * * * * * * * * * * * * * * * * * * * * *\end{array}$} \\
\hline & \multicolumn{2}{|c|}{$\begin{array}{l}\text { ICE BUYERS WHO } \\
\text { COULD HAVE } \\
\text { PURCHASED EHV1 } \\
\star \star \star \star \star \star \star \star \star \star \star \star \star \star \star \star \star \star\end{array}$} & \multicolumn{2}{|c|}{$\begin{array}{l}\text { ICE BUYERS WHO } \\
\text { COULD HAVE } \\
\text { PURCHASED EHV2 } \\
\star \star \star \star \star \star \star \star * * * \star * \star \star\end{array}$} \\
\hline & EHV 1 & ICE & EHV2 & ICE \\
\hline \multicolumn{5}{|l|}{ VEHICLE } \\
\hline $\operatorname{cosT}(W / 0$ SUBSIDY) & 8000 & 5975. & 0. & 0. \\
\hline RESALE VALUE & 2534 & 4080 & 0. & 0. \\
\hline NET DEPRECIATION & 5466 . & 4080 & 0. & 0 \\
\hline \multicolumn{5}{|l|}{ BATTERY } \\
\hline $\operatorname{cosT}(W / 0$ SUBSIDY $)$ & 1300. & 0 . & 0. & 0. \\
\hline SALVAGE & 411 & 0. & 0. & 0. \\
\hline NET DEPRECIATION & 889. & 0. & 0. & 0 . \\
\hline TOTAL VEH. AND BAT. & 6355. & 4080. & 0. & 0. \\
\hline \multicolumn{5}{|l|}{ OPERATING AND MAINTENANCE } \\
\hline FUEL & 8. & 2462 . & 0. & 0. \\
\hline ROAD TAX & 276. & 0. & 0. & 0. \\
\hline OTHER, FIXED & 828. & 828. & 0. & 0. \\
\hline OTHER, VARIABLE & 626. & 783. & 0. & 0. \\
\hline TOTAL $0 \cdot$ AND $M$ & 1738. & 4073 & 0. & 0. \\
\hline GROSS & 8093. & 8153. & 0. & 0. \\
\hline LESS: SUBSIDY & 0. & 0. & 0. & 0. \\
\hline LESS: WARRANTY & 1513. & 0. & 0. & 0. \\
\hline NET DISCOUNTED & & & & \\
\hline LIFE-CYCLE COSTS & 6580 & 8153. & 0. & 0. \\
\hline
\end{tabular}


DO YOU WANT TO PRINT THE FOLLOWING TABLES?

..TABLE D.2..(UTILITIES SECTOR)

TYPE (0) FOR NO OR TYPE (1) FOR YES 0

DO YOU WANT TO PRINT THE FOLLOWING TABLES?

. TABLE D. 3.. (POLICE SECTOR)

TYPE (0) FOR NO OR TYPE (1) FOR YES 0

DO YOU WANT TO PRINT THE FOLLOWING TABPES?

..TABLE D.4..(GOVT SECTOR)

TYPE (0) FOR NO OR TYPE (1) FOR YES 0

DO YOU WAPT TO TRIPT TIE TOLLOWINO TADLE3?

..TABLE D.5.. (ALL SECTORS)

TYPE (0) FOR NO OR TYPE (1) FOR YES 0

STOP

1.745 CP SECONDS EXECUTION TIME 
APPENDIX G 


\section{A. Background to Glossary}

CPEN (Fleet-Car Market PENetration Simulator) is a FORTRAN program written for use on Brookhaven National Laboratory's CDC 6600 computer. It is an interactive program operable from remote (including non-BNL) terminals. It uses a data base comprised of information collected from 142 Fleet operators. Each fleet operator, or respondent, could indicate a preference for a base car described in the questionnaire, or alternatively, for as many as three respondent-described "optional cars." The CPEN user enters data to describe two hypothetical vehicles, termed EHV1 and EHV2, whose physical attributes are compared to those needed by the base vehicle and by the optional cars. If an EHU has physical attributes that make it suitable for use as the base vehicle or as an optional car, it is considered "applicable" for such use. CPEN then performs an economic comparison of the EHV and a comparable internal-combustion-engine (ICE) car, and determines which vehicle the respondent would purchase to minimize costs. All CPEN dollar amounts are stated in March 1979 dollars.

The respondents are classified by their main business activity, or market sector. The market sectors are: business, utilities, police, and state \& local goveraments. For internal computations, CPEN segregates cars into small, medium, and large on the basis of seating capacity, with small cars having fewer than 5 seats, medium cars having 5 seats, and large cars having 6 or more seats.

In the CPEN computer coding certain subscripts are reserved for special uses. The subscript $\mathrm{J}$ indicates market sector. When $\mathrm{J}$ equals 5 , the subscripted variable in question is usually a sum or average of all sectors. The subscript $\mathrm{K}$ indicates FHV1 or EHV2, and the subscript $\mathrm{L}$ indicates which of the respondent's vehicles is being dealt with. That is, $K$ values of 1 or 2 respectively indicate EHV1 and EHV2, and $L$ values of 1,2 , and 3 respectively indicate optional cars 1,2, and 3 . An L value of 4 indicates the base car. 
B. Glossary

ADU

$\operatorname{AIR}(L)$

$\operatorname{AVCAP} 1(I, J, K)$

$\operatorname{AVCAP} 2(\mathrm{I}, \mathrm{J}, \mathrm{K})$

$\operatorname{BATBAS}(K)$

BATMO

BATRNG (K)

BP

$\operatorname{BUYEV}(I, J, K)$
Average daily usage of the typical car within a market sector. Days on which vehicle is idle are not used to compute average. Miles per day.

A dummy variable indicating whether the respondent needs air conditioning on optional car L. $\operatorname{AIR}(L)$ values of 1 or 0 indicate respectively whether car does or does not need air conditioning.

Average capitalized costs of acquiring EHVI or EHV2, as perceived by a respondent who rejected EHV1 or EHV2 on basis of cost only (i.e., they were applicable). I denotes cost category, $J$ denotes market sector, and $\mathrm{K}$ denotes EHV1 $(\mathrm{K}=1)$ or EHV2 $(K=2)$.

Average capitalized costs of acquiring an ICE, where $K$ denotes which EHV the ICE is designed to compete with. See $\operatorname{AVCAPl}(I, J, K)$.

Base price (ignoring subsidy) of EHV battery.

The lifetime of an EHV battery, given the average depth of discharge (i.e., DEPTH) that a specific EHV battery would experience when used in a particular optional car. Months.

EHV range, when operating on batteries only. Miles per recharge.

Business sector weighting factor (3174).

Number of EHVs purchased, after eliminating EHV1 and EHV2 overlap (see F1gure 3 in text). 
$\operatorname{BQUYPR}(I, J, K)$

$\operatorname{CAR}(M)$
The Buy Price maker takes the base price of each respondent optional car and adds it to the sum of the max. Procedure for all the attributes to give a final price value of each optional car. In the task of making the prices more realistic if a car with 4 seats or less has a price under $\$ 5000$, then $t$ is ralsed to that amount. If a car with 5 seats has a price under $\$ 6000$, then it is raised to 6000 , and for a car with 6 seats or more is not at leaset $\$ 6900$, then the price is raised to $\$ 6900$.

The NAFA survey data, where CAR Indicates the attributes of the optional car being tested at a particular time in the program and $M$ denotes questionnalre items as follows:

\section{VARIABLE}

1. Seating Option

2. Trunk Space Option

3. Performance Option $(\mathrm{Y} / \mathrm{N})$

4. Recharge Hours Option

5. Range

5. Healei ( $\mathrm{Y} / \mathrm{N})$

7. $\mathrm{A} / \mathrm{C}(\mathrm{Y} / \mathrm{N})$

8. $\mathrm{P} / \mathrm{S}(\mathrm{Y} / \mathrm{N})$

9. $P / B(Y / N)$

10. Reliability Option

11. Utilization Rate

12. Maximum Price for Seating Option

13. Maximum Price for Trunk Option

14. Maximum Price for Performance Option

15. Maximum Price for Recharge Option

16. Maxtmum Price for Range Option

17. Maximum Price for Heater Option

18. Maximum Price for A/C Option

19. Maximum Price for $P / S$ Option

20. Maximum Price for P/B Option 
21. Maximum Price for Reliabllity Option

22. Total Cars in Fleet

23. Base Percentage

24. MIX Number

CARS

The total number of a respondent's cars that need the capabilities dictated by the respondent.

CYCLES

DAYMO

The Iifetime of an EHV battery, given the average depth of discharge (i.e., DEPTH) that a spectfic EHV battery would experience when used in a particular optional car. Recharge cycles. The market sector average monthly number of days that a car is operated (as opposed to standing idle).

DEPTH

$\operatorname{DESMIV}(K)$

The EHV battery's average depth of discharge, as a percent of full charge.

The design mileage of the EHV vehicle (1.e., vehicle lifetime in miles), exclusive of battery lifetime.

DU

Average daily usage of a respondent-described optional car. Days on which vehicle is idle are not used to compute average. Miles per day.

$\operatorname{ECAR}(I, J, K)$

Number of EHVs purchased, but contains EHVI and EHV2 overlap (see Figure 3 in text).

$\operatorname{ECARP}(I, J, K)$

Base prices (including battery and subsidy) of EHVs in $\operatorname{ECAR}(\mathrm{I}, \mathrm{J}, \mathrm{K})$.

$\operatorname{ECARPV}(\mathrm{I}, \mathrm{J}, \mathrm{K})$

The capitalized cosț of cars in $\operatorname{ECAR}(I, J, K)$.

EHBAS (K)

Base price (ignoring subsidy) of EHV vehicle, exclustve of battery.

$\operatorname{EHBUY}(\mathrm{J}, \mathrm{K})$

The estimated number of EHVs that would be purchased by the respondents. 
EHCAP

EHPRI

$\operatorname{EHSKIP}(J, K)$

HHVAPỶ $(I, J, K)$

EัÜM

EPRICE

ESHARE

FIXOML

FIXOMM

FIXOMS
The estimated capitalized cost of acquiring a specific EHV for use as a particular optional car.

Base price (including battery and subsidy) of an EHV acquired for use as a particular optional car.

The estimated number of ICEs purchased by respondents in instances where they could have purchased an EHV.

The unuler of ICEs purchaocd in caooo where an EHV was applicable.

Electric vehicle monthly variablo nonfuel operating and malntenance costs, as a decimal fraction of comparable ICE costs. Cost items consist of oll, tires, repair (less recoverles), maintenance, washing, and miscellaneous incidental expenses.

The price of electricity purchased for recharg1ng EHV balleries. Döllars per kflowatthour.

The estimated decimal fraction of vehicle mileagc for which a given hybrid vehicle would be propelled by batteries alone.

The market sector monthly average costs for large car fixed operating and maintenance expenses. Cost 1tems consist of license, taxes (other than fuel taxes), parking, tolls, and insurance.

The market sector monthly average costs for medium car fixed operating and maintenance expenses. See FIXOML.

The market sector monthly average costs for small car fixed operating and maintenance expenses. See FIXOML. 
FUEL ( $K$ )

GASP

GP

HOLDMO

$\operatorname{ICEBUY}(J)$

ICECAP

ICEPRI

INSURE

INT

$\operatorname{LIFCYI}(K)$

$\operatorname{LIFCY2}(K)$
A dummy variable indicating the fuel type of an EHV. FUELL(K) values of 0,1 , and 2 respectively denote vehicles that use liquid fuels exclusively, electricity exclusively, and some combination of liquids and electricity.

The price of gasoline or other liquld fuel purchased to refuel. ICEs and hybrid vehicles. Dollars per gallon.

Government sector weighting factor (645).

The market sector average number of months that a car is held by the original owner.

The estimated number of ICEs purchased by respondents in instances where they could have purchased an EHV. Related to $\operatorname{EHSKIP}(\mathrm{J}, \mathrm{K})$ but does not distinguish which EHV the ICE purchaser could have bought.

The estimated capitalized cost of acquiring an ICE for use as a particular optional car.

The price of an ICE acquired for use as a particular optional car. Includes automatic transmission. Also includes air conditioning, power steering, and power brakes if a competing ËHV is so equipped.

The monthly per vehicle cost of collision and liabtiity insurance.

The sectoral average monthly discount rate.

The lifetime of the EHV battery, assuming that the battery is fully discharged on each cycle. Recharge cycles.

The lifetime of the EHV battey, assuming that the battery's average depth of discharge is $65 \%$. Recharge cycles. 
$\operatorname{LMPG}(\mathrm{K})$

LPRI

MMPG

MPRI

$\operatorname{MPRICE}(L)$

$\operatorname{MSHARE}(\mathrm{J}, \mathrm{N})$

NETAPP(M)

$\operatorname{NONAPP}(\mathrm{J})$

$\operatorname{PAPPV}(J, \mathrm{~L})$
Fuel consumption of a large ICE with automatic transmission. Miles per gallon.

Base price of large ICE, exclusive of all options except automatic transmission.

Fuel consumption of medium ICE with automatic transmission. Miles per gallon.

Base price of medium ICE, exclusive of all options except automatic transmission.

The maximum price a respondent was willing to pay tor optional car L. The IIts.lmum price is equal to the electric car base price appearing on the respondent's questlomalle form, plus the prices the respondent entered next to each of the ten optional car attributes:

The estimated decimal fraction of the market sector sample that would buy EHVI (designated by $N=1)$, buy EHV2 $(N=2)$, buy either EHV1 or EHV2 ( $N=3)$, buy an ICE $(N=4)$, buy efther an EHV or an ICE $(N=5)$, or buy no car $(N=6)$.

The market sector number of ICEs purchased in Instances where Ellvs were applicable, after eliminating overlap between EHV1 and EHV2.

The number of market sector sample cars for which hoth EHV1 and EHV2 are nonapplicable. That is, neither has physical capabilities sufficient to be considered for purchase, rcgardless of their price.

Markec cector applicatility ratca for EHV1 $(\mathrm{L}=1)$ and EHV2 $(\mathrm{L}=2)$. PAPPV $(\mathrm{J}, 3)$ shows EHV1 and EHV2 applicability overlap (see Figure 3 in text) and $\operatorname{PAPPV}(\mathrm{J}, 4)$ is the total applicability of both EHV1 and EHV2, with overlap eliminated. 
PBRAKE (L)

$P C(I, J, K)$

P.P

PSTEER (L)

PVBBUY

PVBSAl

PVBSA2

PVBSA3

PVBSAL

PVBUY 2

PVBUY 3
A dummy variable indicating whether the respondent needs power brakes on optional car L. PBRAKE(L) values of 1 or 0 indicate respectively whether car does or does not need power brakes.

Indicates whether EHVI $(\mathrm{K}=1)$ and EHV2 $(\mathrm{K}=2)$ are applicable to respondent's optional car. EHV is applicable if $\operatorname{PC}(I, J, K)=10$.

Police sector welghting factor (291).

A dummy variable indicating whether the respondent needs power steering on optional car $L$. PSTEER(L) values of 1 or 0 indicate respectively whether car does or does not need power steering.

The present value of the series of batteries purchased in order to use a specific EHV as a particular optional car.

The present value of the salvage value of the first battery worn out by a specific EHV, when the EHV is used as a particular optional car.

Same as PVBSAl, but for second battery worn out.

Same as PVBSAl, but for third battery worn out. The present value of the salvage values of all the batteries purchased for a spectflc EHV, when the EHV is used as a particular optional car.

The present value of the second battery purchased (as a replacement for the first battery) for a specific EHV used as a particular optional car.

Same as PVBUY2, but for third battery. 
PVBUY 4

PVC

PVEVAR

PVEVSE

PVE IXM

DYCASE

PVGASI

PVICEF
Same as PVBUY2, but. for fourth battery.

The market sector present value coefficient. Shows the present value of a series of one dollar payments (or recelpts) occurring at the end of each month that a vehicle is held by the original owner.

The present value of the electricity purchased for a specific EHV, during the period the EHV is used as a particular optional car.

The present value of the "other, variable" component of a specific EHV's operating and mainccinance costs, for the pestud the EUV is used as a particular optional car. See PVICEV for cost items included.

The present value of a specific EHV (exclusive of battery) at vehicle trade-in, when the EHV is used as a particular optional car.

The present value of the "other, fixed" component of a specific EHV's operating and maintenance costs, for the period the EHV is used as a pailicular uptional car. Ecc FIXOML for cost items included.

The present value of the gasoline or other liquid fuel purchased to refuel a specific hybrid car, for the period the vehicle ts used as a partlcular optional car.

The present value of the gasoline or other 11quid fusl puscliassid to rafllel a spertfic. ICE, for the period the vehicle is used as a particular optional car.

The present valuc of the "othar, fixed" component of a specific ICE's operating and maintenance costs, for the period the ICE is used as 
a particular optional car. See FIXOML for cost items included.

PVICEV

The present value of the "other, variable" component of a specific ICE's operating and malntenance costs, for the period the ICE is used as a particular optional car. Cost items include oil, tires, repairs (less recoveries), maintenance, wasting, and miscellaneous incidental expenses.

PVICSE

The present value of a specific ICE at vehicle trade- $I n$, when the ICE is used as a particular optional car.

PVLAST

PVTAX

PVTRAD

PVWAR

The present value of the salvage value of the last battery purchased for a specific EHV, when the EHV is used as a particular optional car.

The present value of a specific EHV's road tax, when the EHV is used as a particular optional car.

The market sector present value of one dollar received at vehicle trade in.

The present value of a 3-year warranty covering a vehicle's collision and liability insurance, maintenance and repairs, and a free loaner while repairs are being made.

RANGE(L) The range specified by the respondent for optional car L. Miles.

$\operatorname{RELY}(K)$

$\operatorname{SALES}(J, M)$

The EHV unscheduled annual number of days in shop.

The estimated annual number of cars sold in a market sector, where $M=1$ denotes EHV1 sales, $M=2$ denotes'EHV2 sales, $M=3$ denotes total $E H V$ sales, $M=4$ denotes ICE sales, $M=5$ denotes total sales, $M=6$ denotes sales lost due to high 


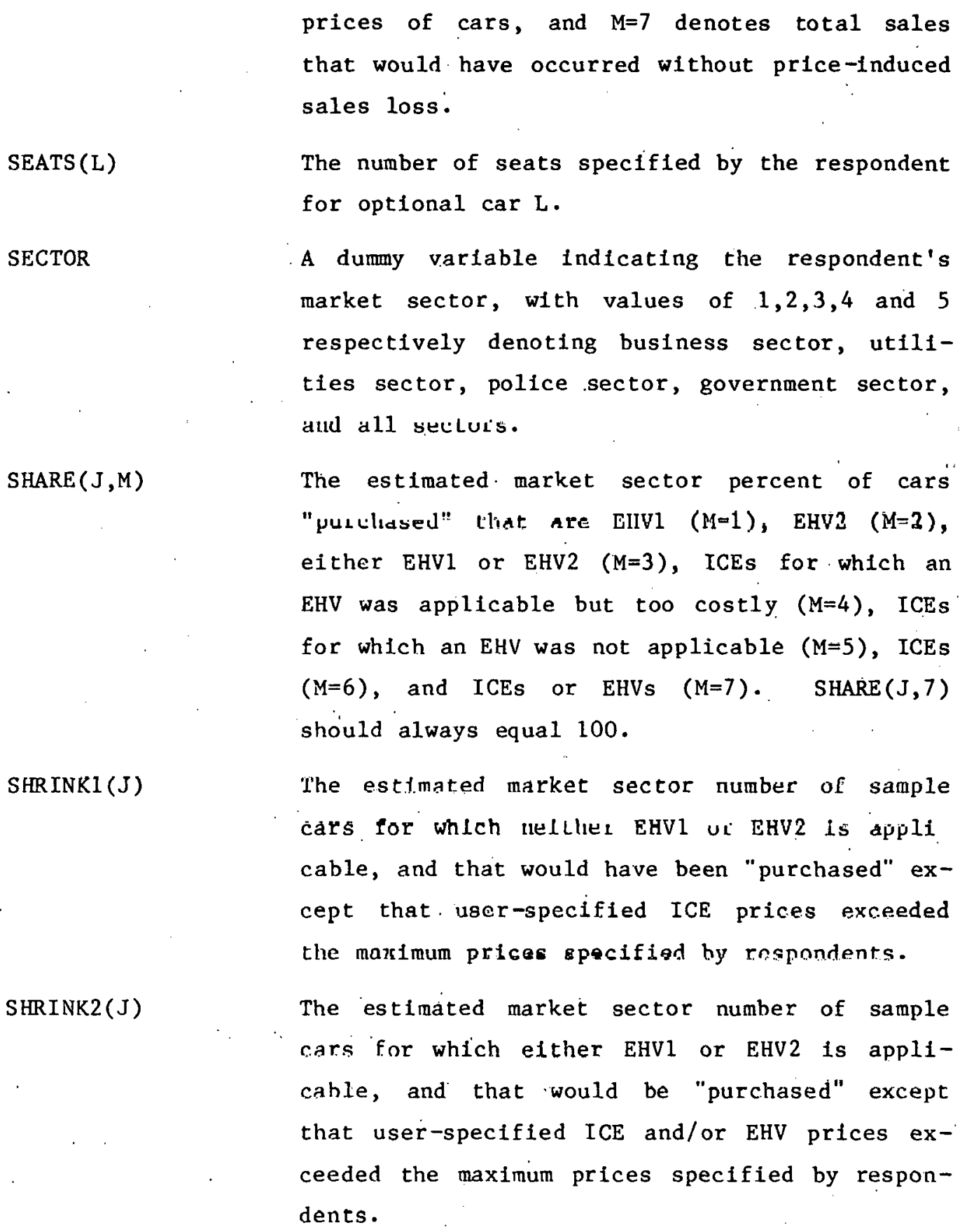




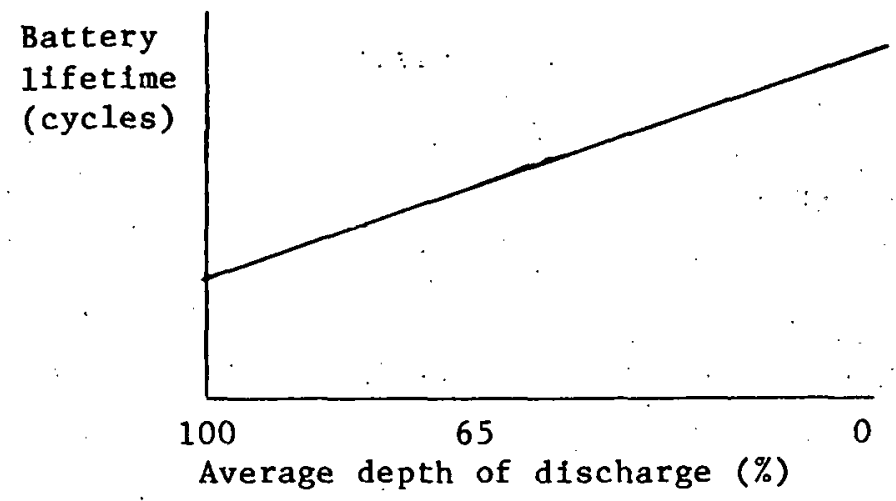

SMPG

Fuel consumption of small ICE with automatic transmission. Miles per gailon.

SPRI

Base price of small ICE, exclusive of ali options except automatic transmission.

$\operatorname{SUB}(K)$

The purchase subsidy on EHV $K$.

$\operatorname{SUMCAP}(I ; J, K)$

$\operatorname{SUMICE}(\mathrm{I}, \mathrm{J}, \mathrm{K})$

The capitalized cost's of all EHVs that were applicable, but were rejected on the basis of cost. I denotes cost category, $J$ denotes market sector, and $\mathrm{K}$ denotes EHV1 or EHV2.

The capitalized costs of all ICEs "purchased" by respondents in situations where an EHV was applicable: I denotes cost category, $J$ denotes market sector, and $K$ denotes which EHV the ICE is designed to compete with.

See $\operatorname{SUMCAP}(1, J, K)$.

$\operatorname{TOTBUY}(\mathrm{J})$

The estimated number of cars (both EHVs and ICEs) "purchased" by respondents in situations where either EHV1 or EHV2 was applicable. Will

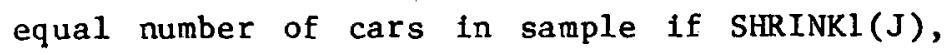
$\operatorname{SHRINK} 2(\mathrm{~J})$, and $\operatorname{NONAPP}(\mathrm{J})$ are all equal to zero.

$\mathrm{TP}$

Total of sectoral weighting factors (4639).

UP

Utility sector weighting factor (529). 
VTRADE

WAR (K)

WARICV

WARPVC
The decimal fraction of vehicle (exclusive of battery) lifetime remaining at vehicle trade $-i n$.

A dummy variable indicating whether an EHV carries a special 3-year warranty covering: collision and 11ability insurance, maintenance and repairs, and a free loaner vehicle. WAR(K) values of 1 and 0 indicate respectively whether EHV does or does not have warranty.

The present value of the variable operating and mafintenánce costs that would be covered under a special 3-ycar warranty (oce WAR(K)), accuming a vehicle has variable operating and maintenance costs equal to that of an ICE. See PCICEV fur 1lst of variable $0 \& M$ cost items.

The market sector present value coefficient used for discounting a special 3-year warranty (see WAR $(K))$. Shows the present value of a series of one dollar payments (or receipts) occurring at the end of each month that the vehicle is both under warranty and owned by the original owner. 
APPENDIX H 
PROGRAM CPEN ( INPUT, OUTPUT, TAPE2, TAPE5= INPUT, TAPE3=OUTPUT)

REAL CAR, DUM, BOTH, NE I THER, ONLYI, ONLYZ, TOTMIX, ZZ, RELY,

+SHR I NK I , SHR I NK2, NONAPP, EOM, EPR I CE , GASP, SMPG, MMPG, LMPG, L IFCY I , L I FCY

+2 , EHBUY, ICEBUY, AVCAP 1 , AVCAPZ, CARSAL, MSHARE, SALES, EHSK IP , SHARE, SUMC

+ AP. SUMICE, TOTBUY, INT, ICECAP, ICEPR I , DROP, EHVAPP, ECAR, ECARP, ECARPV,

+BUYEV, DEPRES, NET TAP , TOTMKT, APPV, PAPPV , TOTEHV , NONA

INTEGER F, POINT, PC, M, N, BUYPR, L,

+FUEL, WAR, SPR I , MPR I , LPRI , DESMIV, EHBAS, SUB, BATRNG, BATBAS

DIMENSION $F(2,10)$, BUYPR $(142,4)$,

+BOTH(4), NE I THER (4), ONLY I (4), ONI Y2 (4), TOTMIX (4), TOTEHV (4),

+ APPV $(4,4)$, PAPPV $(4,4)$, DEPRE $(142,2), \operatorname{NONA}(142,2)$,

+SHR I NK I ( 5 ) , SHR I NK2 ( 5$)$, NONAPP ( 5$)$, FUEL (2), EHBAS ( 2 ), SUB (2), WAR (2) ,

+EOM(2), LIFCYI (2), LIFCY2 (2), DESMIV (2), BATRNG (2),BATBAS ( 2$)$,

+ AVCAPI $(16,5,2), \operatorname{AVCAPZ}(16,5,2), \operatorname{EHBUY}(5,2), \operatorname{EHSKIP}(5,2), \operatorname{CARSAL}(5)$,

+ ICEBUY (5), MSHARE $(5,7), \operatorname{SALES}(5,7), \operatorname{SHARE}(5,7), \operatorname{TOTBUY}(5)$,

+SUMCAP (9,5,2), SUMICE (6,5,2), RELY (2), TOTMKT (5), UROP (142), NETAPP (5)

LEVEL $2, C A R, P C$, EHVAPP, ECAR, ECARP, ECARPV, BUYEV, DEPRES

COMMON/HELP/ CAR (24),PC (142,3,2), EHVAPP $(142,4,2), E C A R(142,4,2)$,

$+\operatorname{ECARP}(142,4,2), \operatorname{ECARPV}(142,4,2)$, BUYEV $(142,4,2), \operatorname{DEPRES}(142,4,2)$

$c$
$c$
$c$

TIRST ARD SECOND CARO ATTRIQUTES READ IN INTERACTIVELY

WRI TE $(3,97)$

WRITE $(3,96)$

WRITE $(3,120)$

WRITE (3,121)

READ ( 5 * * POINTO

ट IF (POINTG.EQQ. I.) $6010 \%$

$3 \mathrm{I}=1$

WRI TE $(3,98)$

GO TO 6

5 WRI TE $(3,99)$

6 WRITE $(3,100)$

$\operatorname{READ}(5, *) \quad F(1,1)$

WRITE $(3,101)$

$\operatorname{READ}(5, *) \quad F(1,2)$

WRITE (3,102)

WRITE $(3,103)$

$\operatorname{READ}(5 ;) F(1,3)$

WRI TE $(3,104)$

$\operatorname{READ}(5, *) F(1,4)$

WRI TE $(3,105)$

READ $5, * 1$ F I I, 5)

WRI TE $(3,106)$

WRI TE $(3,103)$

$\operatorname{READ}(5, *) F(1,6)$

WRI TE (3, 107)

WRI TE $(3,103)$

$\operatorname{READ}(5, *) \quad F(1,7)$

WRITE $(3,108)$

WRI TL $(3,103)$

READ $(\bar{s}, \times) \Gamma(1, \Omega)$

WRI TE $(3,109)$

WR ITF $(3.103)$

$\operatorname{READ}(5, x) F(1,9)$

WRITE $(3,110)$

RE $\triangle M 15, *) F(1,1 \cap)$

IF (1.EQQ. ए) GO TO 10

IF (I.EQ.1) $1-\bar{z}$

IF (1.EQ.2) GO TO 5

10 WRI TE $(3,200)$

WRI TE $(3,201)$

WRITE $(3,202) \quad(F(I, 1), 1=1,2)$

WRITE $(3,203) \quad(F(1,2), 1=1,2)$

WRITE $(3,204) \quad(F(1,3), 1=1,2)$

WRITE $(3,205) \quad(F(1,4), 1=1,2)$

WRI TE $(3,206) \quad(F(1,5), I=1,2)$

WRITE $(3,207) \quad(F(1,6), 1=1,2)$ 


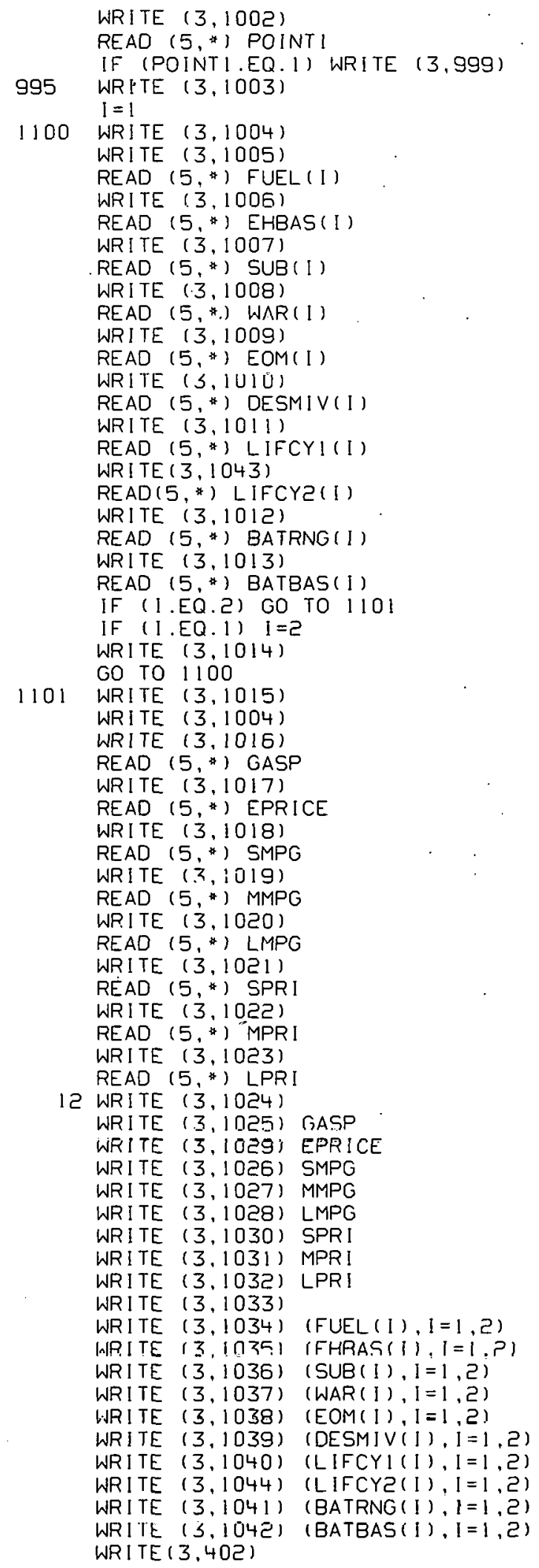




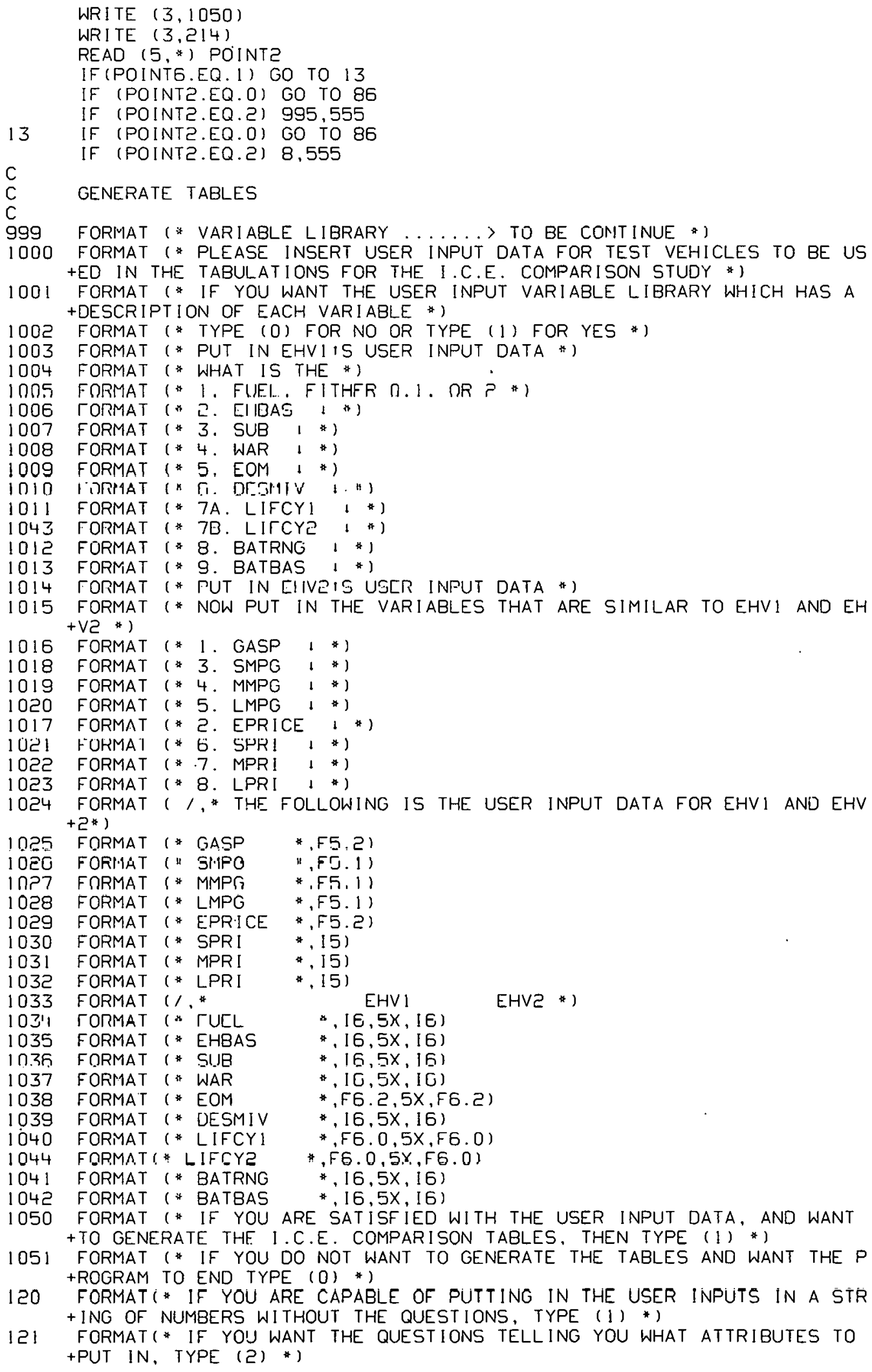


WRI TE $(3,208) \quad(F(1,7), I=1,2)$

WRI TE $(3,209) \quad(F(1,8), I=1,2)$

WRITE $(3,210) \quad(F(1,9), I=1,2)$

WRITE $(3,211) \quad(F(1,10), I=1,2)$

WRI TE $(3,213)$

WR I TE $(3,214)$

$\operatorname{READ}(5, *)$ POINT

IF (POINT.EQ.2) GO TO 2

IF (POINT6.EQ.1) 8,14

97 FORMAT * THIS IS THE FORTRAN DUEL SIMULATOR FJR CARS USING THE DAT +A COLLECTED FROM NAFA, *)

96 FORMAT ( YOU WILL INTERACTIVELY PUT IN THE ATTRIBUTES FOR TWO CARS + AND THEY WILL BE RUN THROUGH THE SIMULATOR. *)

99 FORMAT ( PUI IN THE SECONO CARS ATTRIBUTES*)

98 FORMAT ( PUT IN THE FIRST CARS ATTRIBUTES*)

100 FORMAT (* 1. SFATING OPTION IS!*)

101 FORMAT ( 2. WHAT IS THE TRUNK CAPACITY, (IN CU.FT.) )*)

102 FORMAT ( 3 . DOES IT HAVE A PERFORMANCE OPTION! *)

103 FORMAT ( TYPE (0) FOR NO OR TYPE (1) FOR YES *)

104 FORMAT * 4. HOW MANY HOURS OF RECHARGE IS NEEDED । *)

105 FORMAT ( 5. WHAT IS THE VEHICLES RANGE CAPACITY *)

106 FORMAT $* 6$. DOES THE VEHICLE HAVE A HEATER: *)

107 FORMAT ( * 7: DOES THE VEHICLE HAVE A AIR CONDITIONER! * )

108 FORMAT ( * 8. DOES THE VEHICLE HAVE POWER STEERING । *)

109 FORMAT ( * 9. DOES THE VEHICLE HAVE POWER BRAKES I *)

110 FORMAT ( 10. HOW MANY DAYS PER YEAR CAN THE CAR BE INCAPACITATEDI + RELIABILITY *)

200 FORMAT ( THE FOLLOWING IS THE DATA FOR THE TWO CARS ATTRIBUTES*)

201 FORMAT ( *

202 FORMAT * SEATING OPTION

203 FORMAT ( TRUNK SPACE * 19,5X,110)

204 FORMAT ( PERFORMANCE OPTION * $19,5 \times, 110$ )

205 FORMAT ( RECHARGE * 19,5X, I10)

206 FORMAT ( RANGE * 19,5X,110)

207 FORMAT ( HEATER * $19,5 \times, 110$ )

208 FORMAT ( AIR CONDITIONER *,19,5X, I10)

209 FORMAT ( POWER STEERING *,19,5X, I10)

210 FORMAT ( POWER BRAKES * 19,5X, I10)

211 FORMAT ( RELIABIL ITY OPTION *,19,5X, I 10 )

213 FORMAT ( $/ *$ IF YOU ARE SATISFIED WITH THE VARIABLES AND WANT TO CON + TINUE TYPE (1)*)

214 FORMAT ( IF YOU WANT TO CHANGE ANY ONE OR ALL OF THE VARIABLES TYP $+E(5) *$

7 WRITE $(3,122)$

$\operatorname{READ}(5, *)(F(1, J), J=1,10)$

WRITE $(3,123)$

$\operatorname{READ}(5, *) \quad(F(2, J), J=1,10)$

C GO TO 10

$8 \quad J=1$

WR I TE $(3,1400)$

9

READ (5* *) FUEL (I), EHBAS (I), SUB (I),WAR( I ), EOM( I), DESMIV ( I ), LIFCYI( I

+ ), LIFCYZ( I), BATRNG (I), BATBAS (I)

IF (1.EQ.2) GO TO 11

WR ITE $(3,1401)$

$i=5$

GO TO 9

11 WRITE $(3,1402)$

READ (5,*) GASP, EPRICE , SMPG, MMPG , LMPG , SPR I ,MPRI , LPR I

GO TO 12

$\mathrm{C}$
$\mathrm{C}$
$\mathrm{C}$
$\mathrm{C}$

INTERACTIVE INPUT USERS DATA FOR EHVI AND EHVR

14 WRITE $(3,402)$

WR I TE ( 3,402$)$

WR I TF $(3,402)$

80 WRITE $(3,1000)$

WRITE $(3,1001)$ 


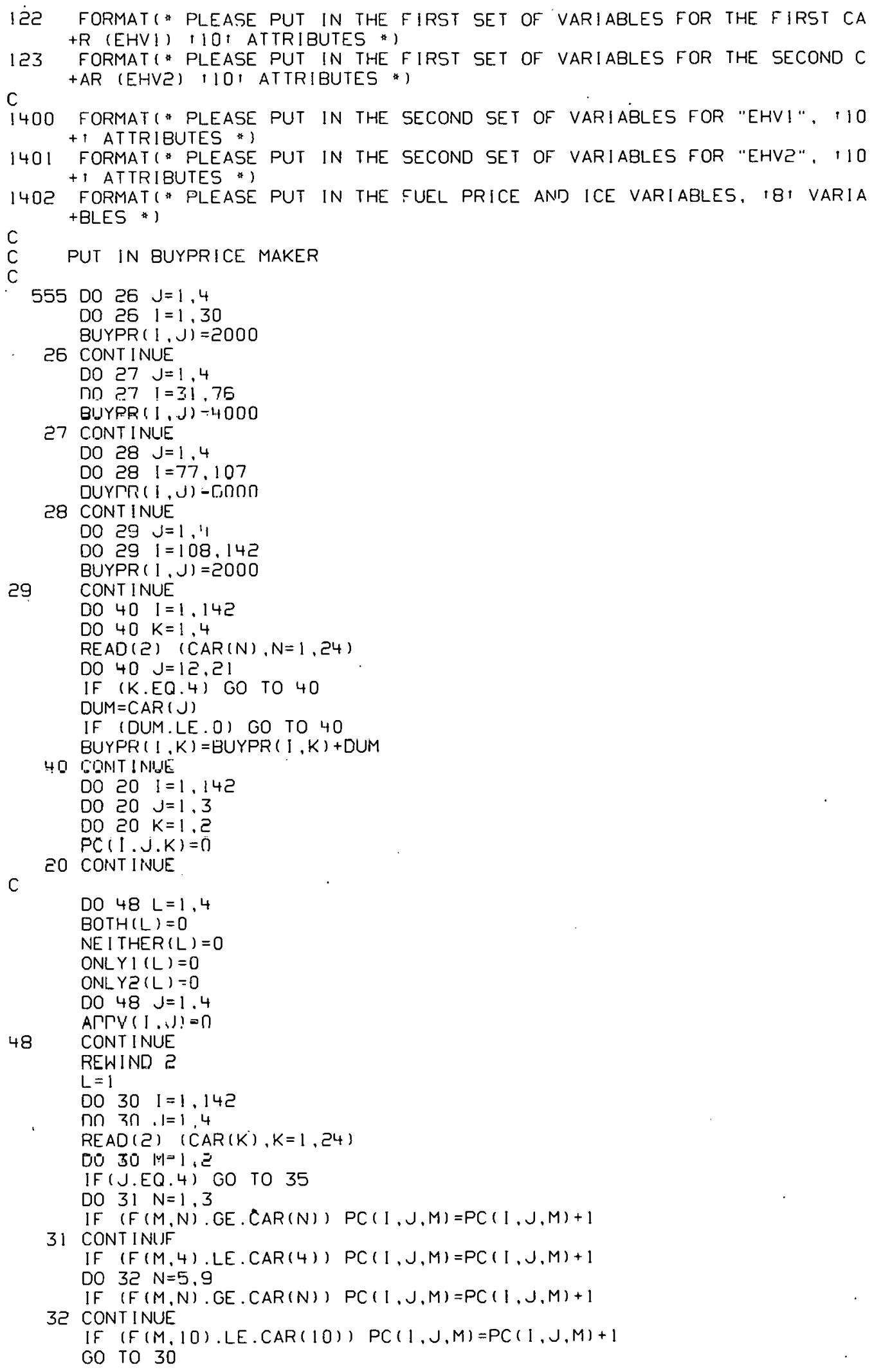

DO $48 \mathrm{~L}=1,4$

BOTH $(L)=0$

NE I THER $(L)=0$

ONLYI $(L)=0$

ONLYZ $(L)=0$

DO $48 \quad J=1.4$

АГГИ ( I . S)! = त

48 CONTINUE

REWIND?

$L=1$

DO $30 \quad I=1,142$

กก $3 \cap .1=1,4$

$\operatorname{READ}(2)$ (CAR $(K), K=1,24)$

DO $30 \quad|y|=1,2$

IF (J.EQ.4) GO TO 35

DO $31 \mathrm{~N}=1,3$

IF $(F(M, N), G E, C A R(N)) P C(I, J, M)=P C(1, J, M)+1$

31 CONTINUF

IF $(F(M, 4), L E \cdot C A R(4)) \quad P C(1, J, M)=P C(I, J, M)+1$

DO $32 N=5,9$

IF $(F(M, N), G E \cdot C A R(N)) \quad P C(1, J, M)=P C(1, J, M)+1$

32 CONTINUE

IF $(F(M, 10) . L E . C A R(10)) P C(1, J, M)=P C(I, J, M)+1$

GO TO 30 


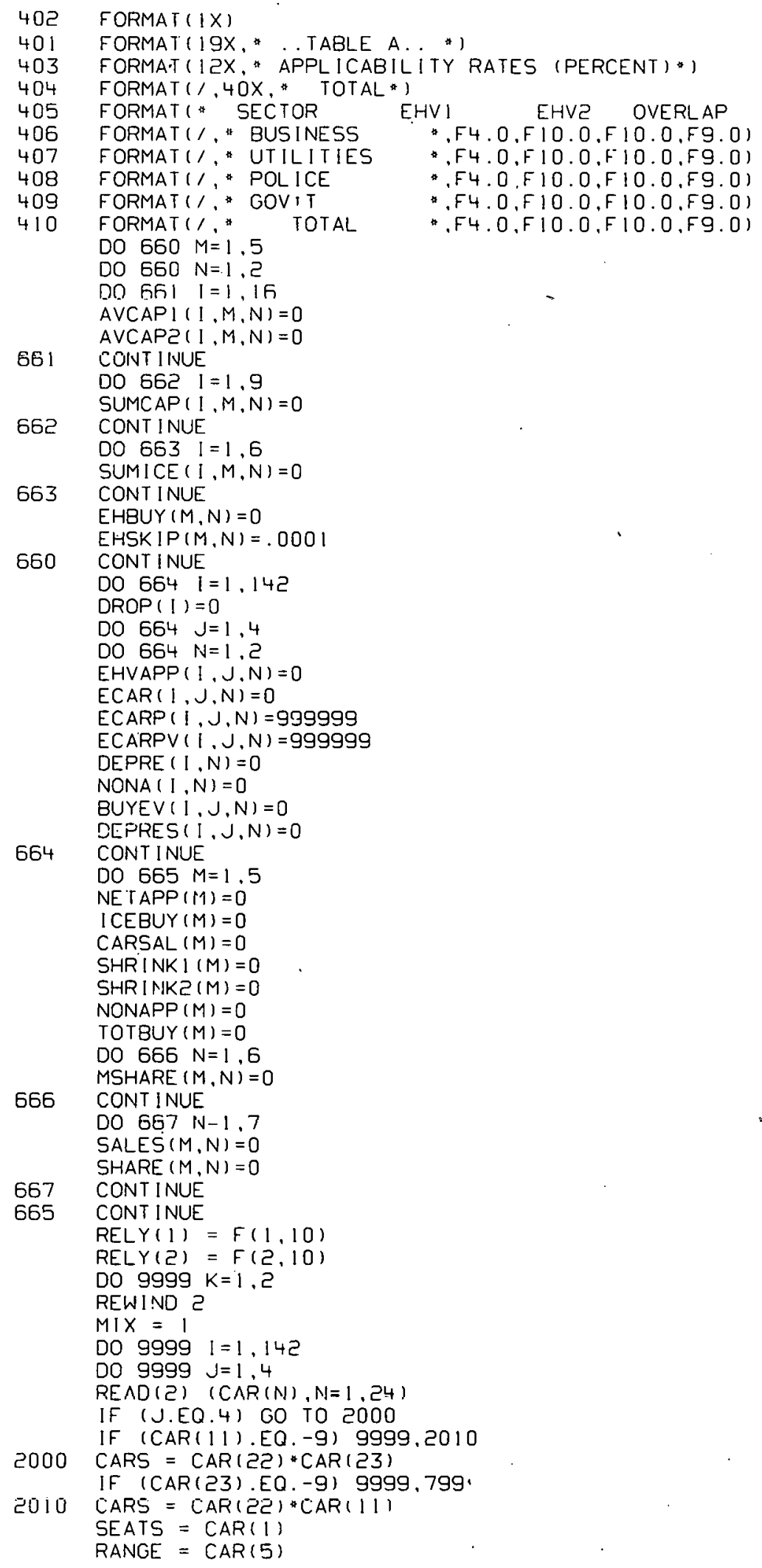




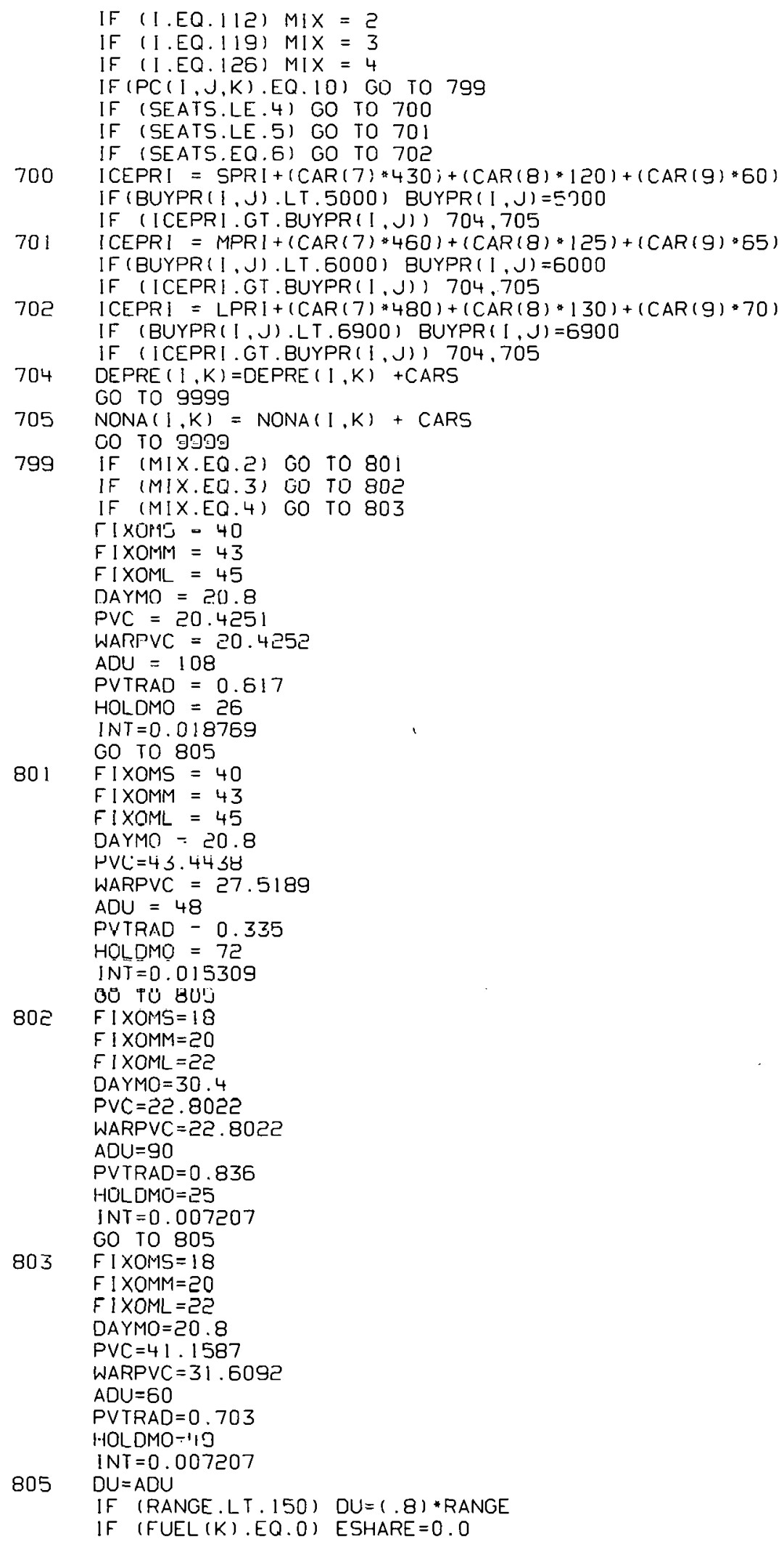


IF (WAR (K).EQ. I )PVWAR $=($ WARPVC * INSURE $)+($ WARICV*( (EOM $(K)$ *ESHARE $)+(1-E$ +SHARE $))+(($ RELY $(K)-($ HOLDMO/ 12$))$ 20 )

PVEVSE =PVTRAD* (EHBAS $(K) * V T R A D E)$

PVICSE =PVTRAD*(ICEPRI *((100000-1DAYMO*DU*HOLDMO $) / 100000))$

$P V I C E F=P V F I X M$

PVGASE $=$ PVGASI * (1-ESHARE $)$

EHPR $I=E H B A S(K)+B A T B A S(K)-S U B(K)$

$E H C A P=E H B A S(K)+P V B B I J Y \quad-S U B(K)-P V W A R-P V E V S E+P V E L+P V G A S E+P V T A X+P V F$

+ I XM+PVEVAR-PVBSAL

ICECAP = I CEPR I -PV ICSE +PVGAS I +PV ICEF + PV ICEV

C

IF (EHCAP.GT.ICECAP) GO TO 825

IF (EHPRI.GT.BUYPRII,J)) GO TO 830

$835 \operatorname{ECAR}(1, J, K)=\operatorname{CARS}$

$\operatorname{ECARP}(I, J, K)=E H P R I$

ECARPV $(i, j, K)=E H C A P$

GO TO 9999

825 IF (ICEPRI.GT.BUYPR(I,J)) GO TO 840

GO TO 850

840 IF (EHPRI.LE.BUYPR(I,J) GO TO 835

841 OEPRES $(1, J, K)=$ CARS

GO TO 9999

830 IF (ICEPRI.GT.BUYPR $(1, J))$ GO TO 841

C INSERT

850. M=MIX

EHSKIP $(M, K)=E H S K I P(\mid 1, K)+$ CARS

EHSKIP $(5, K)=\operatorname{EHSKIP}(5, K ;+$ CARS

$\operatorname{EHVAPP}(1, J, K)=$ CARS

SUMICE $(1, M, K)=\operatorname{SUMICE}(1, M, K)+($ ICEPR I *CARS $)$

SUMICE $(1,5, K)=\operatorname{SUMICE}(1,5, K)+($ ICEPRI *CARS $)$

$\operatorname{SUMCAP}(1, M, K)=\operatorname{SUMCAP}(1, M, K)+(P V E V S E * C A R S)$

$\operatorname{SUMCAP}(1,5, K)=\operatorname{SUMCAP}(1,5, K)+(P V E V S E * C A R S)$

$\operatorname{SUMCAP}(2, M, K)=\operatorname{SUMCAP}(2, M, K)+($ PVBBUY *CARS $)$

$\operatorname{SUMCAP}(2,5, K)=\operatorname{SUMCAP}(2,5, K)+($ PVBBUY*CARS $)$

SUMICE $(2, M, K)=$ SUMICE $(2, M, K)+(P V I C S E$ *CARS $)$

SUMICE $(2,5, K)=\operatorname{SUMICE}(2,5, K)+(P V I C S E * C A R S)$

$\operatorname{SUMCAP}(3, M, K)=\operatorname{SUMCAP}(3, M, K)+(P V B S A L$ *CARS $)$

$\operatorname{SUMCAP}(3,5, K)=\operatorname{SUMCAP}(3,5, K)+($ PVBSAL *CARS $)$

$\operatorname{SUMCAP}(4, M, K)=\operatorname{SUMCAP}(4, M, K)+((P V G A S E+P V E L) * C A R S)$

$\operatorname{SUMCAP}(4,5, K)=\operatorname{SUMCAP}(4,5, K)+((P V G A S E+P V E L) *$ CARS $)$

SUMICE $(3, M, K)=\operatorname{SUMICE}(3, M, K)+(P V G A S I *$ CARS $)$

SUMICE $(3,5, K)=\operatorname{SUMICE}(3,5, K)+(P \vee G A S I * C A R S)$

$\operatorname{SUMCAP}(5, M, K)=\operatorname{SUMCAP}(5, M, K)+(P \vee T A X * C A R S)$

$\operatorname{SUMCAP}(5,5, K)=\operatorname{SUMCAP}(5,5, K)+(P \vee T A X * C A R S)$

$\operatorname{SUMCAP}(6, M, K)=\operatorname{SUMCAP}(6, M, K)+(P V F(X M * \operatorname{CARS})$

$\operatorname{SUMCAP}(6,5, K)=\operatorname{SUMCAP}(6,5, K)+(P V F I X M * C A R S)$

SUMICE $(4, M, K)=\operatorname{SUMICE}(4, M, K)+(P V F$ IXM*CARS $)$

SUMICE $(4,5, K)=\operatorname{SUMICE}(4,5, K)+(P V F I X M * C A R S)$

SUMCAP $(7, M, K)=\operatorname{SUMCAP}(7, M, K)+(P V E V A R * C A R S)$

$\operatorname{SUMCAP}(7,5, K)=\operatorname{SUMCAP}(7,5, K)+(P V E V A R * C A R S)$

SUMICE $(5, M, K)=$ SUMICE $(5, M, K)+(P V I C E V * C A R S)$

SUMICE $(5,5, K)=\operatorname{SUMICE}(5,5, K)+(P V I C E V * C A R S)$

$\operatorname{SUMCAP}(8, M, K)=\operatorname{SUMCAP}(8, M, K)+(P V W A R * C A R S)$

SUMCAP $(8,5, K)=\operatorname{SUMCAP}(8,5, K)+($ PVWAR*CARS $)$

$\operatorname{SUMCAP}(9, M, K)=\operatorname{SUMCAP}(9, M, K)+(E H C A P * C A R S)$

$\operatorname{SUMCAP}(9,5, K)=\operatorname{SUMCAP}(9,5, K)+(E H C A P * C A R S)$

SUMICE $(G, M, K)=$ SUMICE $(G, M, K)+($ ICECAP CARS $)$

SUMICE $(6,5, K)=\operatorname{SUMICE}(6,5, K)+(I$ ICECAP *CARS $)$

$\operatorname{AVCAP} 1(1, M, K)=\operatorname{EHBAS}(K)$

$\operatorname{AVCAPZ}(1, M, K)=\operatorname{SUMICE}(1, M, K) / \operatorname{EHSK} I P(M, K)$ $\operatorname{AVCAPI}(2, M, K)=\operatorname{SUMCAP}(1, M, K) / E H S K I P(M, K)$ $\operatorname{AVCAP} 2(2, M, K)=\operatorname{SUM} I C E(2, M, K) / E H S K I P(M, K)$ $\operatorname{AVCAP} \mid(4, M, K)=\operatorname{SUMCAP}(2, M, K) / E H S K I P(M, K)$ $\operatorname{AVCAPZ}(4, M, K)=0.0$

$\operatorname{AVCAPI}(5, M, K)=\operatorname{SUMCAP}(3, M, K) / \operatorname{EHSKIP}(M, K)$ $\operatorname{AVCAPZ}(5, M, K)=0.0$

$\operatorname{AVCAP} I(8, M, K)=\operatorname{SUMCAP}(4, M, K) / \operatorname{EHSK} I P(M, K)$ $\operatorname{AVCAPZ}(8, M, K)=\operatorname{SUMICE}(3, M, K) / \operatorname{EHSKIP}(M, K)$ 
F (FUEL (K).EQ. 1) ESHARE $=1.0$

IF (FUEL (K).EQ.2) ESHARE $=0.65 * B A T R N G(K) / D U$

IF (ESHARE.GT.1.0) $E S H A R E=1.0$

VTRADE $=($ DESMIV $(K)-(D U * D A Y M O * H O L D M O) / / D E S M I V(K)$

IF (VTRADE. LE . .05) VTRADE $=.05$

IF (SEATS.LE.4) GO TO 811

IF (SEATS.EQ.5) GO TO 812

IF (SEATS.GE.6) GO TO 813

811 PVTAX=PVC * (DAYMO*DU*0.0071*ESHARE)

IF (BUYPR( I.J).LT.5000) BUYPR ( I,J) $=500 \mathrm{n}$

PVGASI =PVC "DAYMO *DU* (CASP/SMPC)

PVF IXM=PVC $* F I X O M S$

ICEPR I $=$ SPR I + (CAR $(7) * 430)+(\operatorname{CAR}(8) * 120)+(\operatorname{CAR}(9) * 60)$

PVEL $=$ PVC *DAYMO*DU*ESHARE*(EPRICE $/ 100) *(($ BATRNG $(K) * .00099)+.22)$

$P V I C E V=P V C * D A Y M O * D U * .020$

I NSURE $=18$

WAR ICV =WARPVC DAYMO*DU* .020

GO TO 815

RID PVTAX=PVC (DAYMO*DU*.0076*ESHARE

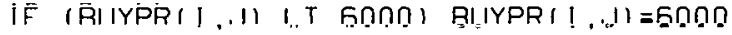

PVGAS I =PVC * DAYMO * DU* (GASP/MMPG)

PVF IXM $=P V C$ F IXOMM

ICEPR I $=$ MPR I + (CAR (7)*460) + (CAR (8)*125) + (CAR (9)*65)

$P V E L=P V C * D A Y M O * D U * E G H I A R E *(E A R I C E, 100) *((B \wedge T R M G(K) * .0 C 009)+.22) * 1.1$

PVICEV $=P V C * D A Y M O * D U * .024$

INSURE $=20$

WARI I V =WARPVC "DAYMO*DU".024

GO TO 815

813 PVTAX=PVC *(DAYMO*DU*.DL81*ESHARE)

IF (BUYPR(I, J).LT.6900) BUYPR ( I,J)=6900

PVGASI =PVC *DAYMO*DU* (GASP/LMPG)

$P V F I X M=P V C * F I X O M L$

ICEPRI $=$ LPRI + (CAR $(7) * 480)+($ CAR $(8) *(30)+($ CAR $(9) * 70)$

PVEL $=P V C * D A Y M O * D U * E S H A R E *(E P R I C E / 100) *((B A T R N G(K) * .00099)+.22) * 1.2$

PVICEV $=P V C * D A Y M O * D U * .024$

INSIJRE $=25$

WARICV=WARPVC *DAYMO*DU*.024

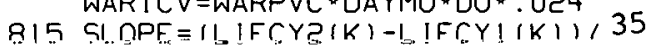

DEPTH $=100-(i$ DU/BATRNG $(K)) * 100)$

CYCLES $=$ (SLOPE $*$ DEPTH ) + IFCYI $(K)$

IF (FUEL (K).EQ.3) CYCLES=LIFCYZ $(K)$

HVBUY $=U . U$

$\Gamma \vee D U Y 3=0$

PVBUY $4=0$

PVBSA $1=0$

$P V B S A 2=0$

PVBSA $3=0$

BATMO $=$ CYCLES $/$ DAYMO

NIJMBAT $=1$

IF(HOLDMO.LT.BATMO) GO TO 777

NUMBAT -NUMBAT+1

PVBUYZ=BATBAS $(K) /((1.0+I N T) * B A T M O)$

PVRSA $1=0.1$ "PVRIJYP

IF (HOLDMO.LT. (E.O*BATMO)) GO TO 777

NUMBAT $=$ NUMBAT +1

PVRI IY, $3=R A T R A S(K) /((1, n+I N T) *(P . n * R A T M \cap))$

PVBSAC $=0.1$ *PVBUY 3

IF (HOLDHIOLT.(3.0*BATHO)) BO TO 777

NUMBAT $=$ NUMBAT +1

PVBUY $4=B A T B A S(K) /((1,0+[N T) *(3,0 * B A T M O))$

PVBSA $3=0.1$ *PVBUY 4

IF (HOLDMO.LT. (4.0*BATMO)) GO TO 777

PVBUY $4=9999999999$

777 PVLAST $=$ BATBAS $(K) *((($ NUMBAT *BATMO $)-$ HOLDMO $) / B A T M O)$ *PVTRAD

PVBBUYY=BATBAS $(K)+P V B U Y \bar{Z}+P V B U Y \overline{3}+\tilde{P} V \overline{B U Y} 4$

$P V B S A L=P V B S A 1+P V B S A E+P V B S A 3+P V L A S T$

$=\quad P V E V A R=P V I C E V *((E O M(K) * E S H A R E)+(1-E S H A R E))$

C ******INSERT (6)***********

PVWAR $=0: 0$ 
$\operatorname{AVCAP} !(G, M, K)=\operatorname{SUMCAP}(5, M, K) / E H S K ! P(M, K)$ $\operatorname{AVCAP2}(9, M, K)=0.0$

$\operatorname{AVCAPI}(10, M, K)=\operatorname{SUMCAP}(6, M, K) / E H S K I P(M, K)$

$\operatorname{AVCAPD}(10, M, K)=\operatorname{SUMICE}(4, M, K) / E H S K I P(M, K)$ AVCAPI $(11, M, K)=\operatorname{SUMCAP}(7, M, K) / E H S K I P(M, K)$ $\operatorname{AVCAPC}(11, M, K)=\operatorname{SUMICE}(5, M, K) / E H S K I P(M, K)$ $\operatorname{AVCAPI}(14, M, K)=$ SUB $(K)$

$\operatorname{AVCAP2}(14, M, K)=0.0$

$\operatorname{AVCAPI}(15, M, K)=\operatorname{SUMCAP}(8, M, K) / \operatorname{EHSKIP}(M, K)$

AVCAП $2(15, M, K)=0.0$

$\operatorname{AVCAP} 1(16, M, K)=\operatorname{SUMCAP}(9, M, K) / E H S K I P(M, K)$ $\operatorname{AVCAP2}(16, M, K)=\operatorname{SUMICE}(G, M, K) / \operatorname{EHSKIP}(M, K)$ $\operatorname{AVCAP}|(3, M, K)=\operatorname{AVCAP}|(1, M, K)-\operatorname{AVCAP} \mid(2, M, K)$ $\operatorname{AVCAP} I(6, M, K)=\operatorname{AVCAP} 1(4, M, K)-\operatorname{AVCAP} 1(5, M, K)$ $\operatorname{AVCAP}|(7, M, K)=\operatorname{AVCAP}(3, M, K)+\operatorname{AVCAP}|(6, M, K)$

$\operatorname{AVCAP}|(12, M, K)=\operatorname{AVCAP} 1(8, M, K)+\operatorname{AVCAP}|(9, M, K)+\operatorname{AVCAP} \mid(10, M, K)+\operatorname{AVCAP} 1(1$ $+1, M, K)$

$A V C A P I(13, M, K)=A V C A P \mid(7, M, K)+\operatorname{AVCAPI}(12, M, K)$

$\operatorname{AVCAP}(3, M, K)=\operatorname{AVCAP} 2(1, M, K)-\operatorname{AVCAP} 2(2, M, K)$

$\operatorname{AVCAPZ}(6, M, K)=\operatorname{AVCAPZ}(4, M, K)-\operatorname{AVCAPZ}(5, M, K)$

$\operatorname{AVCAPD}(7, M, K)=\operatorname{AVCAP} 2(3, M, K)+\operatorname{AVCAPZ}(5, M, K)$

$\operatorname{AVCAP} 2(12, M, K)=\operatorname{AVCAP} 2(8, M, K)+\operatorname{AVCAP} 2(9, M, K)+\operatorname{AVCAP} 2(10, M, K)+\operatorname{AVCAP} 2(1$

$+1, M, K)$

$\operatorname{AVCAP} 2(13, M, K)=\operatorname{AVCAP} 2(7, M, K)+\operatorname{AVCAP} 2(12, M, K)$

9999 CONTINUE

DO $730 k=1 \ldots$ END OF BIG LOOP

$\operatorname{AVCAPI}(1,5, K)=\operatorname{EHBAS}(K)$

$\operatorname{AVCAPZ}(1,5, K)=\operatorname{SUMICE}(1,5, K) / \operatorname{EHSK} I P(5, K)$

$\operatorname{AVCAPI}(2,5, K)=\operatorname{SUMCAP}(:, 5, K) / \operatorname{EHSKIP}(5, K)$

$\operatorname{AVCAP} 2(2,5, K)=\operatorname{SUM} I C E(2,5, K) / E H S K I P(5, K)$

$\operatorname{AVCAPI}(4,5, K)=\operatorname{SUMCAP}(2,5, K) / \operatorname{EHSK} I P(5, K)$.

$\operatorname{AVCAP} 2(4,5, K)=0.0$

$\operatorname{AVCAPI}(5,5, K)=\operatorname{SUMCAP}(3,5, K) / \operatorname{EHSKIP}(5, K)$

$\operatorname{AVCAP} 2(5,5, K)=0.0$

$\operatorname{AVCAP} I(8,5, K)=\operatorname{SUMCAP}(4,5, K) / \operatorname{EHSK}[P(5, K)$

$\operatorname{AVCAP} 2(8,5, K)=\operatorname{SUM} I C E(3,5, K) / E H S K I P(5, K)$

$\operatorname{AVCAPI}(9,5, K)=\operatorname{SUMCAP}(5,5, K) / E H S K I P(5, K)$

$\operatorname{AVCAPC}(9,5, K)=0.0$

$\operatorname{AVCAPI}(1 \dot{0}, 5, K)=\operatorname{SUMCAP}(6,5, K) / \operatorname{EHSKIP}(5, K)$

$\operatorname{AVCAPC}(10,5, K)=\operatorname{SUMICE}(4,5, K) / E H S K I P(5, K)$

$\operatorname{AVCAPI}(11,5, K)=\operatorname{SUMCAP}(7,5, K) / \operatorname{EHSKIP}(5, K)$

$\operatorname{AVCAPC}(11,5, K)=\operatorname{SUMICE}(5,5, K) / \operatorname{EHSKIP}(5, K)$

$\operatorname{AVCAPI}(14,5, K)=\operatorname{SUB}(K)$

$\operatorname{AVCAPC}(14 ; 5, K)=0.0$

$\operatorname{AVCAPI}(15,5, K)=\operatorname{SUMCAP}(8,5, K) / \operatorname{EHSKIP}(5, K)$

$\operatorname{AVCAPZ}(15,5, K)=0.0$

$\operatorname{AVCAPI}(15,5, K)=\operatorname{SUMCAP}(9,5, K) / \operatorname{EHSKIP}(5, K)$

$\operatorname{AVCAPC}(16,5, K)=\operatorname{SUMICE}(6,5, K) / \operatorname{EHSKIP}(5, K)$

$\operatorname{AVCAPI}(3,5, K)=\operatorname{AVCAP}(1,1,5, K)-\operatorname{AVCAP} 1(2,5, K)$

$\operatorname{AVCAP}(6,5, K)-\operatorname{AVCAP}|(4,5, K)-\operatorname{AVCAP}|(5,5, K)$

$\operatorname{AVCAP} I(7,5, K)=\operatorname{AVCAP} I(3,5, K)+\operatorname{AVCAPI}(6,5, K)$

$\operatorname{AVCAP} \mid(12,5, K)=\operatorname{AVCAP} I(8,5, K)+\operatorname{AVCAP} I(9,5, K)+\operatorname{AVCAP} I(10,5, K)+\operatorname{AVCAP} I(1$

$+1,5, K)$

$\operatorname{AVCAP} 1(13,5, K)=\operatorname{AVCAP}(17,5, K)+\operatorname{AVCAPI}(12,5, K)$

$\operatorname{AVCAPZ}(3,5, K)=\operatorname{AVCAP} 2(1,5, K)-\operatorname{AVCAPZ}(2,5, K)$

$\operatorname{AVCAP2}(6,5, K)=\operatorname{AVCAPC}(4,5, K)-\operatorname{AVCAP} 2(5,5, K)$

$\operatorname{AVCAP} 2(7,5, K)=\operatorname{AVCAP} 2(3,5, K)+\operatorname{AVCAPZ}(6,5, K)$

$\operatorname{AVCAP} 2(12,5, K)=\operatorname{AVCAP} 2(8,5, K)+\operatorname{AVCAP} 2(9,5, K)+\operatorname{AVCAP} 2(10,5, K)+\operatorname{AVCAP} 2(1$

$+1,5, K)$

$\operatorname{AVCAPC}\left(13,5, k^{\prime}\right)=\operatorname{AVCAP} 2(7,5, k)+\operatorname{AVCAP} 2(12,5, k)$

730 CONTINUE

$M I X=1$

UU $\%$ I U $\quad I=1,14 \dot{C}$

DO $740 \quad J=1,4$

IF (I.EQ.1Iट) $M I X=2$

IF (I.EQ. 119 ) $M I X=3$

IF (I.EO. I EG) $M I X=4$

$E \mid=\operatorname{EHVAPP}(1, J, 1)$ 


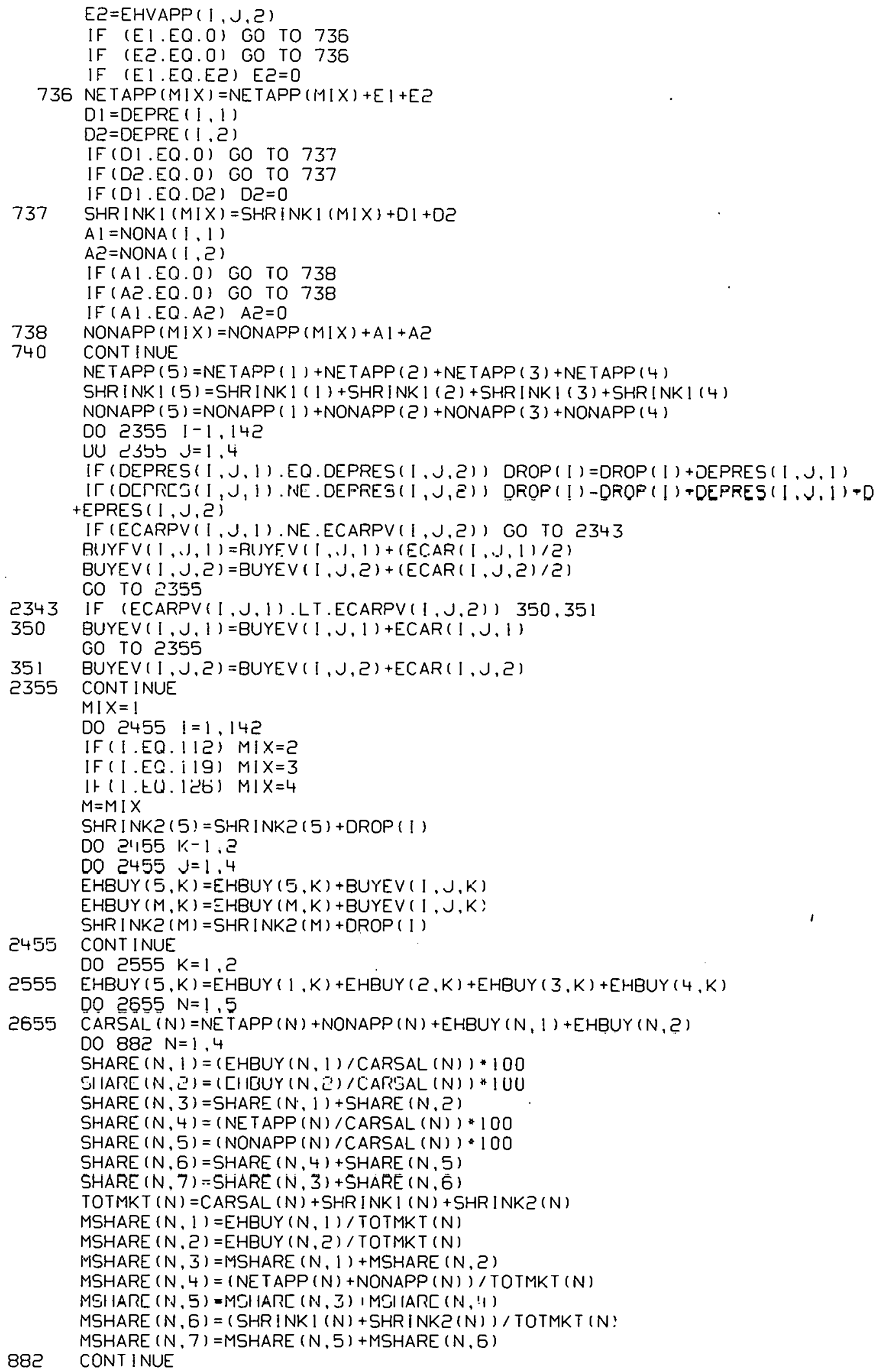


DO $884 \mathrm{~N}=1.7$

$\operatorname{SALES}(1, N)=\operatorname{MSHARE}(1, N) * 895$

$\operatorname{SALES}(2, N)=\operatorname{MSHARE}(2, N) * 56$

$\operatorname{SALES}(3, N)=\operatorname{MSHARE}(3, N) * 87$

$\operatorname{SALES}(4, N)=\operatorname{MSHARE}(4, N) * 99$

$\operatorname{SALES}(5, N)=\operatorname{SALES}(1, N)+\operatorname{SALES}(2, N)+\operatorname{SALES}(3, N)+\operatorname{SALES}(4, N)$

$\operatorname{SHARE}(5, N)=(B P * \operatorname{SHARE}(1, N)+\operatorname{UP} * \operatorname{SHARE}(2, N)+P P * \operatorname{SHARE}(3, N)+G P * \operatorname{SHARE}(4, N$

$+) 1 /$ TP

884 CONTINUE

$\mathrm{C}$
$\mathrm{C}$
$\mathrm{C}$

..FORMATS FOR TABLES...

WR I TE $(3,402)$

WRI TE $(3,402)$

WR I TE $(3,402)$

WRI I TE ( 3,402$)$

WR I TE $(3,402)$

WRITE $(3,1200)$

WRI TE (3,1.201)

WRITE $(3,1202)$

WRITE $(3,1203)$

WRITE $(3,1204)$

WRITE $(3,1205)$ (SHARE $(1,1), I=1,7)$

WRITE $(3,1206)$ (SHARE $(2,1), I=1,7)$

WRITE $(3,1207)$ (SHARE $(3,1), 1=1,7)$

WRITE $(3,1208) \quad(\operatorname{SHARE}(4,1), 1=1,7)$

WRI TE $(3,402)$

WRITE $(3,1209)$ (SHARE $(5,1), I=1,7)$

DO $17 \mathrm{~J}=1,10$

WR I TE $(3,402)$

17

CONT INUE

WRITE $(3,1210)$

WR!TE $(3,1211)$

WRI TE $(3,402)$

WRITE $(3,1212)$

WRITE $(3,1213)$

WRITE $(3,1214)$

WRITE: $\overline{3}, 1215)$

WRI TE $(3,1216)$

WRITE $(3,1217)$

WRITE $(3,1 \overrightarrow{2} 18)$ (SALES $(1, K), K=1,7)$

WR J TE $(3,1219)$ (SALES $(2, K), K=1,7)$

WRITE $(3,1220)$ (SALES $(3, K), K=1,7)$

WRI TE (3,1221) (SALES $(4, K), K=1,7)$

WRITE $(3,402)$

WRITE (3,1222) (SALES $(5, K), K=1,7)$

DO $18 \mathrm{~J}=1,10$

18

WRI TE $(3,402)$

CONT INUE

$F L A G=U$

$\mathrm{K}=0$

$900 \quad K=K+1$

IF (K.EQ.6) GO TO 86

WR! TE ( 3,1260$)$

GO TO 90 !

902 WRITE $(3,103)$

READ (5* ) POINT3

IF (POINT3.EQ.O) GO TO 900

$F L A G=1$

901 IF (K.EQ.1) WRITE (3.1223)

IF (K.EQ.2) WRITE (3.1224)

IF (K.EQ.3) WRITE (3,1225)

IF (K.EQ.4) WRIITE (3,12Zb)

IF (K.EQ.5) WRITE (3,1227)

IF (FLAG.EQ.0) GO TO 902

WRITE $(3,1228)$

WRITE $(3,1239)$

WRITE (3,1262)

WRITE (3.1230) 
WRITE $(3,1270)$

WRI TE $(3,1231)$

WRI TE $(3,1232)$

WRI TE $(3,1233)$

WRI TE (3,1271)

WRI TE ( 3,1234$)$

WRI TE (3, 1235)

WRI TE $(3,1236) \operatorname{AVCAP} 1(1, K, 1), \operatorname{AVCAP} 2(1, K, 1), \operatorname{AVCAP} 1(1, K, 2), \operatorname{AVCAPZ}(1$, $+K, 2$ )

WRITE (3, 1237$)$ AVCAPI $(2, K, 1), \operatorname{AVCAPZ}(2, K, 1), \operatorname{AVCAPI}(2, K, 2), \operatorname{AVCAPZ}(2, K$, $+2)$

WRI TE (3, 1238$)$ AVCAP $1(3, K, 1), \operatorname{AVCAPZ}(3, K, 1), \operatorname{AVCAP} 1(3, K, 2), \operatorname{AVCAPZ}(3, K$, + )

WRI TE $(3,1239)$

WRITE (3, 1236) AVCAPI $(4, K, 1), \operatorname{AVCAP} 2(4, K, 1), \operatorname{AVCAPI}(4, K, 2), \operatorname{AVCAP} 2(4, K$, $+2)$

WRITE (3,1240) AVCAP I (5,K,1), AVCAPC (5,K,1), AVCAPI (5,K,2), AVCAPZ (5,K, +2)

WRI TE (3, 1238$) \operatorname{AVCAPI}(6, K, 1), \operatorname{AVCAPC}(6, K, 1), \operatorname{AVCAPI}(6, K, 2), \operatorname{AVCAP} 2(6, K$, + C.)

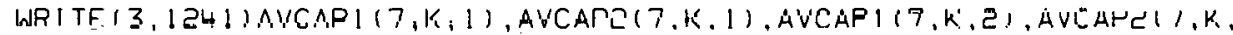
$+\ddot{3}$

WRITE $(3,1242)$

WRITE (3,1243) AVCAP $1(8, K, 1), \operatorname{AVCAPC}(8, K, 1), \operatorname{AVCAPI}(8, K, 2), \operatorname{AVCAPZ}(8, K$, $+2)$

WRITE (3, 1244$)$ AVCAP $1(9, K, 1), \operatorname{AVCAPC}(9, K, 1), \operatorname{AVCAPI}(9, K, 2), \operatorname{AVCAPZ}(9, K$, + ()

WRITE (3,1245) AVCAPI $110, K, 1), \operatorname{AVCAP2}(10, \mathrm{~K}, 1), \operatorname{AVCAP} 1(10, \mathrm{~K}, 2), \operatorname{AVCAPZ}(1$ $+0, K, 2)$

WRITE (3, 1246$)$ AVCAC $1(11, K, 1), \operatorname{AVCAPC}(11, K, 1), \operatorname{AVCAP} \mid 111, K, 2), \operatorname{AVCAPC}(1$ $+0, K, 2)$

WRITE $(3,1247)$ AVCAP $1(12, K, 1), \operatorname{AVCAP2}(12, K, 1), \operatorname{AVCAP} 1(12, K, 2), \operatorname{AVCAPZ}(1)$ $+5, K$, , )

WRITE (3, 1248$)$ AVCAP1 $(13, K, 1), \operatorname{AVCAPC}(13, K, 1), \operatorname{AVCAP} 1(13, K, 2), \operatorname{AVCAPC}(1$ $+3, K, 2)$

WRITE (3,1249) AVCAP1 $(14, K, 1), \operatorname{AVCAPC}(14, K, 1), \operatorname{AVCAP} 1(14, K, 2), \operatorname{AVCAPZ}(1$ $+4, K, 2)$

WRITE (3, I 250) AVCAP $1(15, K, 1), \operatorname{AVCAPC}(15, K, 1), \operatorname{AVCAP} 1(15, K, 2), \operatorname{AVCAPZ}(1$ $+5, K$, ? 1

WRITE (3.1251)

WRI TE (3, ! 2Jट) AVCAP $1(16, K, 1), \operatorname{AVCAPZ}(16, K, 1), \operatorname{AVCAP} 1(16, K, こ), \operatorname{AVCAPC}(1$ $+6, K, 2)$

$F L A C ;=0$ CO TO 900

1200 FORMAT//.2.9X. \# . TARIE B .. *

1201 FOKMAT (19X, * FLEET CAR PENETRATION RATES (PERCENT) *)

1202 FORMAT $\left(1,11 X^{*} \ldots \ldots \ldots\right.$ EHV $\ldots \ldots \ldots * 4 X,{ }^{*} \ldots \ldots \ldots$ ICE $\ldots \ldots$ $+\ldots \ldots \ldots$. . . .

1203 FORMAT (50X * NON- * I6X. * GRAND*)

1204 FORMAT ( SECTOR EHVI EHVE TOTAL APPLICABLE AHPLIC +ABLE TOTAL TOTAL *)

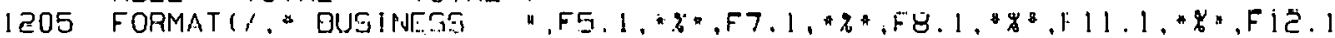
$+* \% * F 10.1, * \% *$,FB.1, * \%*)

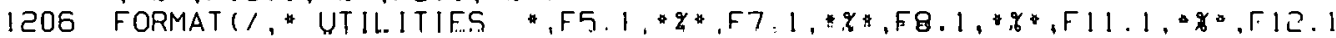
$+, * \% *, F 10.1, * \% *, F 8.1, * \% *)$

1207 FORMATI $1 /$ " POLICE *

1208 FORMATI, "GOVIT

1209 FORMAT(1,* TOTAL * F5.1,***,F7.1,*\%*,F8.1,*\%*,F11.1,***,F12.1 $+, * \%, F 10.1, * \% *, F B .1, * \% *)$

1210 FORMAT (29X; * . TABLE C ..*)

1211 FORMAT (19X: * FLEFT C.AR ANNUIAL SALES (THOUSANDS)*)

1212 FORMAT (/.51X* ADJUSTMENTS FOR*)

1213 FORMAT (5IX, * PRICE-INDUCED*)

I'III FORMATISIX; * DEMAND REDUCTION*)

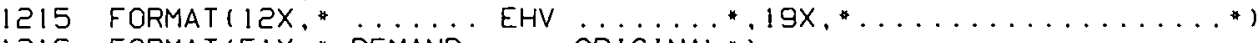

IटI6 FORMAT (5IX, " DEMAND ORIGINAL *

1217 FORMAT(* SECTOR EHVI EHV2 TOTAL ICE TOTAL REDUC 


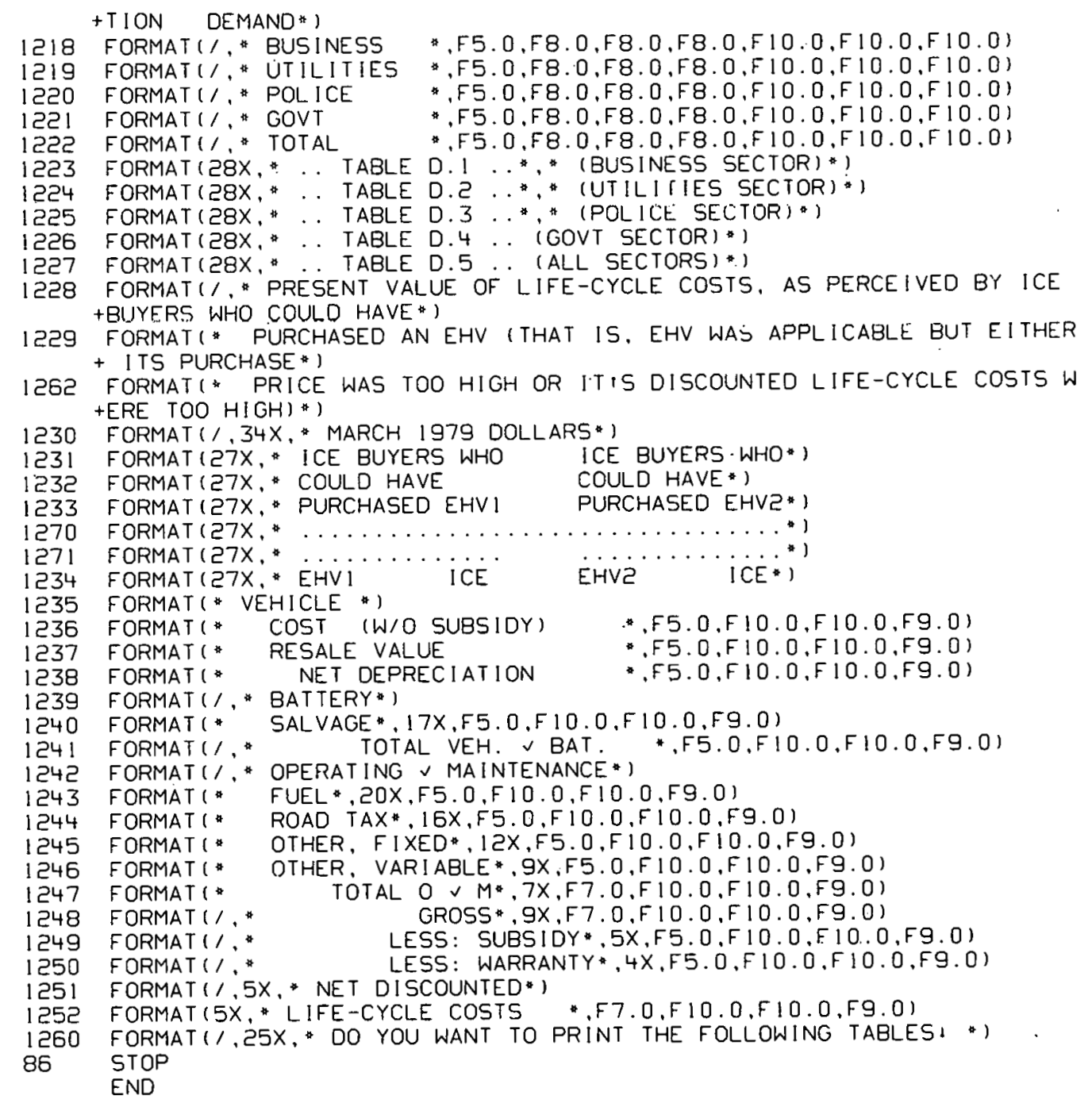

